\title{
HUMAN RIGHTS FOR WOMEN AND WORLD PUBLIC ORDER: THE OUTLAWING OF SEX-BASED DISCRIMINATION *
}

\author{
By Myres S. McDougal, * Harold D. Lasswell ** \\ and Lung-chu Chen
}

As the United Nations commenorates 1975 as "International Women's Year," 1 in a concerted effort to "promote equality between men and women" 2 and to "ensure the full integration of women in the total development effort," 3 the concern of the larger global community for outlawing sex-based discrimination is being articulated with increasing vigor. This concern both builds upon and expresses a more general norm of nondiscrimination which seeks to ban all generic differentiations among people in access to value shaping and sharing for reasons irrelevant to individual capabilities and contribution.* The particular norm against sex-based discrimination finds expression in many authoritative communications, at both international and national levels, and is rapidly being defined in a way to condemn all the great historic deprivations imposed upon women as a group. ${ }^{5}$

- This article is excerpted from a book, Hunan Rights and Wordd Public Order, the authors have in progress. The authors gratefully acknowledge the criticism and comments of Professors W. Michael Reisman and Barbara D. Underwood and Ms. Kreszentia M. Duer and of various members of our 1974 Seminar on Human Rights. The Ralph E. Ogden Foundation has been generous in its support of the studies from which this article is drawn.

- Of the Board of Editors. Sterling Professor of Law, Yale Law School.

$\cdots$ Ford Foundation Professor of Law and Social Sciences, Emeritus, Yale Law School.

0000 Senior Research Associate, Yale Law School.

1 GA Res. 3275 (XXXX) Dec. 10, 1974, Resolutions of the General Assembly at Its Twenty-Ninth Regular Session 207, UN Press Release GA/5194 (Dec. 20, 1974) [hereinafter cited as Res. of the 29th Assembly]; GA Res. 3010, GAOR, 27th Sess. Supp. 30, at 66, UN Doc. A/8730 (1972). See also GA Res. 3276 (XXIX) Dec. 10, 1974, Res. of the 29th Assembly, supra, at 208; GA Res. 3277 (XXIX) Dec. 10, 1974, id. at 209.

2 GA Res. 3275 , supra note 1, at 207; GA Res. 3010, supra note 1, at 67.

${ }^{3}$ Id.

- For detailed elaboration, see McDougal, Lasswell, \& Chen, The Protection of Respect and Human Rights: Freedom of Choice and World Public Order, 24 AM. U. L. REv. No. 4 (forthcoming, Summer 1975).

- $S c c$ authorities cited in notes 96-252 infra and accompanying text. 
I.

\section{FACTUAL BACKGROUND}

The deprivation with which we are here concerned are the discriminations based upon sex, which commonly accord women less favorable treatment than men. ${ }^{6}$ Practices, both governmental and private, that deny

6 The literature on women's rights has mushroomed in recent years. The United Nations is an important source supplying rich materials on the changing status of women around the world, as will become evident in the documentation to follow.

On legal treatment of sex-based discriminations, with primary focus on the United States, see generally B. Babcock, A. Freeman, E. Norton, \& S. Ross, Sex Discrimanation and the Law: Causes and Remedies (1975); K. Davinson, R. Ginsnung, \& H. Kay, Text, Cases and Matertais on Sex-Based Discrintnations (1074); L. Kanowttz, Women and the LaW: The UnFInISHEd Revolution (1969); L. Kanowitz, Sex Roles in Law and Society: Cases and Materuars (1973); S. Ross, The Rights of Women: The Bastc aClu Gume to a Woman's Rughts (1973); Brown, Emerson, Falk, \& Freedman, The Equal Rights Amendment: A Constitutional Basis for Equal Rights for Women, 80 Yare L.J. 872 (1971); Murray, The Rights of Woman, in The Rugers of AMerrcans 521-45 (N. Dorsen ed. 1971); Siedenberg, The Submissive Majority: Modern Trends in the Law Concerning Women's Rights, 55 Cornelx L. Rev. 262 (1970).

For treatment from a wider comparative perspective, see Symposium-The Status of Women, 20 AM. J. CoMp. L. 585 (1972), which deals with women in Great Britain, Sweden, Norway, France, the Soviet Union, Israel, and Senegal. A concise but useful article appears in the latest edition of Encyclopedia Britannica: Klein, Status of Women, 19 EnCYC. BRITANNICA 906 (15th ed. 1974).

On the contemporary Women's Liberation Movement, see the following classic works: S. DE BEauvorr, THE Second Sex (H. Parshley transl. \& ed., Bantam ed. 1961); B. Fruedan, The Feminnine Mystique (1963); K. Milletr, Sexual Poltrics (Avon ed. 1971). See also Fenimism: The Essential Historical Wrutrings (M. Schneir ed. 1972); Liberation Nowl: WrTtings from the Women's Lmenation Movement (Laurel ed. 1971); S. Rowbotham, WoMEN, RESisTance, and REvolution (1972); Sisterhood is PoWerfur (R. Morgan ed. 1970); Vorces of the New FeMaNisM (M. Thompson ed. 1970); Freeman, The New Feminism, Tux Nation, Mar. 9, 1974, at 297-302; Gloria Steinem, NewsweEk, Aug. 16, 1971, at 51-55; The New Woman, 1972, TnEE, Mar. 20, 1972, at 25-34. For a most recent appraisal, see the symposium in commemoration of International Women's Year, in SATURDAY REV., June 14, 1975.

For works on women from a socialist perspective, see F. Engens, The Onicin of the Fammi, Private Property and the State (1942); The Woman Question: Selections from the Wrutings of Kart Marx, Frederuck Engels, V. I. Lendn, Joseph Stalin (1951); A. Bebel, Woman under Socialism (D. de Leon transl. Schocken ed. 1971).

For further general background. readings on women, useful citations include: J. Bardwick, Psychology of Women: A Study of Bio-Cultural Conflicts (1971); W. Chafe, The Amerucan Woman: Her Changing Soclat, Economic, and Polmtical Roles, 1920-1970 (1972); G. Greer, Female Eunuch (1970); E. Janeway, MaN's World, Woman's Place: a Study in Soctad Mythology (1971); T. Lang, The DifFerence betWeen a Man and a Woman (1971); E. Lewis, Deveioping Woman's Potrential (1968); M. Mead, Mare and Female (Dell ed. 1949); M. Mead, Sex and Temperament in Three Prmitrve Soctetres (1935); E. Morgan, The Descent of Woman (1972); A. MYrdat \& V. KIEnN, Women's Two Roles: HOME aNd Wons (1968); The Other Half: Roads to Women's Equality (C. Epstein \& W. Goodo eds. 1971); The Potential of Woman (S. Farber \& R. Wilson eds. 1963); B. \& T. Roszak, Masculine/Femmine (1969); C. Safinjos-Rothschird, Toward a Socrol- 
women the protection and fulfilment of human rights on an equal footing with men are "by no means relics of the past, mere historical curiosities," but continue to be "a fact of life" in the differing communities around the world. " Sex-based discrimination derives in large part from the "arbitrary" division of male and female roles, as culturally defined, that has always existed, in the words of Margaret Mead, "in every society of which we have any knowledge." 8 While the concept of maleness or femaleness differs among cultures, and the specific tasks and responsibilities expected of the two sexes may vary from one society to another, the existence and perpetuation of distinct sex roles, as dictated mostly by men, have characteristically resulted in male-dominated societies in which women are regarded as "the subordinate sex," 9 "the second sex," 10 "the weaker sex," 11 or "the Other." 12 In its most extreme manifestation this deprivation characterizes and treats women as a form of wealth or "property," that is, as

ogy of Woxfen (1972); Sex Roles an Changeng Socnety (G. Seward \& R. Williamson eds. 1970); M. Tunm, Patterns of Society 196-214 (1973); A. Watts, Nature, Man and Woman (Vintage ed. 1970); Women of all Nations: a Record of Themr Characteristics, habits, Manner, Customs and Influence (T. Joyce ed. 1912); The WoMran in AMERTCA (R. Lifton ed. 1965); WoMen IN THE MOdERN World (R. Patai ed. 1967); Women of Tropical Afruca (D. Paulme ed., H. Wright transl. 1963); Wolen's Role in Contemporatry Soctety: THE Report of the New Yonk City Conamission on Hunan Rights (1972); Women, Cutture, and Soctety (M. Rosaldo \& L. Lamphere eds. 1974); Women Around the World, 375 THE ANNars 1 (1968).

A comprehensive, up-to-date bibliography is S. JACOBS, WOMEN IN PERSPECTTVE: a Gume for Cross-Cultural Studies (1974). See also A. Kruchrar, The Women's Rughts MoveneNt IN the Untred States, 1848-1970: A Bibliography and SOURCeBOOK (1972).

7 L. KaNowitz, WoMen and the LAW: The UNFINSHEd REvolution 1 (1969).

${ }^{8}$ M. MEAd, Mare and Fearare, supra note 6, at 39.

In the words of Ralph Linton:

All societies prescribe different attitudes and activities to men and to women. Most of them try to rationalize these prescriptions in terms of the physiological differences between the sexes or their different roles in reproduction. However, a comparative study of the statuses ascribed to women and men in different cultures seems to show that while such factors may have served as a starting point for the development of a division the actual ascriptions are almost entirely determined by culture.

R. Linton, The Study of MAN 116 (1936).

๑ V. Bullough, The Subordinate Sex (Penguin ed. 1974). But see E. Virar, The

MaNipUlated MaN (1972).

10 S. De Beavyorr, supra note 6. But see E. Davis, The First Sex (1971).

21 Untred Nations, Equal Rights for Wodien-A Call for Action 6 (OPI/494,

1973) [hereinafter cited as EquAL Rights For WoMmen].

12 In the words of Simone de Beauvoir:

Thus humanity is male and man defines woman not in herself but as relative to him; she is not regarded as an autonomous being. . . . And she is simply what man decrees; thus she is called "the sex," by which is meant that she appears essentially to the male as a sexual being. For him she is sex-absolute sex, no less. She is defined and differentiated with reference to man and not he with reference to her; she is the incidental, the inessential as opposed to the essential. He is the Subject, he is the Absolute-she is the Other.

S. DE BEAovom, supra note 6, at xvi. 
instruments of production or enjoyment. Paradoxically, the ongoing deprivations caused by sexual differentiation have largely been accepted, consciously or unconsciously, as an inescapable fact of life by the deprivees themselves.

Despite marked improvement in status in recent decades, women around the globe still face "deep and pervasive"" 13 as well as on occasion, "more subtle, discrimination." 14 The deprivations imposed on the ground of sex, both historical and continuing, are in many ways comparable to, though occasionally more pronounced than, those of racial discrimination. ${ }^{16}$ Many severe deprivations are unique to women, especially to married women. ${ }^{10}$

The deprivations women suffer commence with the "second-rung" respect they receive in practically every human society. Widely viewed as "natural appendages of men," 17 "tails wagged by the male ego," ${ }^{28}$ many women are conditioned early in life to look upon themselves as "the Other," whose fulfilment lies in "assisting" and "serving" men. ${ }^{10}$ Thus perceived, women are brought up to be "contented," with a belief in "their inferiority of endowment," in a special "woman's place" ascribed at birth, ${ }^{20}$ and are not encouraged in extravagant demands for equality and other freedoms. In the words of a recent UN study:

Differences in sex roles begin at the moment of birth when the child is first identified as a male or female. From that moment on the child is expected to behave in accordance with the roles customarily assigned to his or her sex. By the time the girl becomes an adult she finds that her world has been slowly but effectively restricted by the

${ }_{13}$ Brown, Emerson, Falk, \& Freedman, supra note 6, at 872.

14 Frontiero v. Richardson, 411 U.S. 677, 686 (1973).

152 G. MYrdal, AN AMERTCAN DILEMaMa 1073-78 (First McGraw-Hill Paperback ed. 1964). See also S. Firestone, The Dialectic of Sex 119-41 (1970); C. Herton, Sex and Racism in America (1966); A. Montagu, Man's Most Dangenous Mytr: The Fallacy of Race 186-89 (5th ed. 1974); Crozier, Constitutionality of Discrimination Based on Sex, 15 B.U.L. Rev. 723, 727-28 (1935); Hacker, Women as a Minority Group, 30 Soctar Forces 60 (1951), reprinted in L. Kanowitz, SEx Roles IN LAw AND Societx 1-8 (1973); Murray \& Eastwood, Jane Crow and the Law: Sex Discrimination and Title VII, 34 GEo. WASH. L. REv. 232, 233-35 (1965).

16 In some respects unmarried mothers suffer additional deprivations. See UNIrED Nations, The Status of the Unmarried Mother: Law and Practice (Report of the Secretary-General), UN Doc. E/CN.6/540/Rev.1 (1971); Legal and Social Status of the Unmarried Mother: Report of the Secretary-General, UN Doc. E/CN.6/562 (1071).

17 H. Hays, The Dangerous Sex 11 (1964).

18 Id.

19 V. Buncough, supra note 9 , at 336 . Betty Friedan asserts that "the core of the problem for women today is not sexual but a problem of identity-a stunting or evasion of growth that is perpetuated by the feminine mystique." B. Fruedan, supra note 6 , at 69 .

20 As in the case of the Negro, women themselves have often been brought to believe in their inferiority of endowment. "As the Negro was awarded his "place" in society, so there was a "woman's place." In both cases the rationalization was strongly believed that men, in confining them to this place, did not act against, the true interest of the subordinate groups. The myth of the "contented women," who did not want to have suffrage or other civil rights and equal opportunities, has the same social function as the myth of the "contented Negro."

2 G. MYrdar, supra note 15, at 1077. 
rules and expectation of others. She learns that being born female sets her apart from men and limits her rights in law and in practice. ${ }^{21}$

Hence, the generic status ascribed to women is sometimes compared to that of a caste. ${ }^{22}$

In the power process, the participation of women lags far behind that of men. In some communities women are still denied the right to vote and to hold public offices. ${ }^{23}$ Where the right of voting and officeholding is formally recognized, there is in fact a conspicuous underrepresentation of women at all levels of government, especially in higher decisionmaking positions.". "After half a century of women's suffrage," in the words of Klein, "the number of women in higher positions of political power and influence is still small enough for them to be known by name." ${ }^{25}$ When women do hold key public offices, they tend to be confined to such "women's spheres" as social welfare, public health, and family affairs. Women may further, where the jury system prevails, be excluded from serving on juries. ${ }^{26}$

Under the inherited doctrines that "a woman has no legal existence separate from her husband" who is "head of the family" ${ }^{2 \tau}$ and that "the unity

21 EQual Rrghts For Wonten, supra note 11, at 6.

i2 C. Andreas, Sex and Caste in Aserica (1971). See also Dunbar, Female Liberation as the Basis for Social Revolution, in SIsTERhood is Powerfor, supra note 6, at 477-92; Freeman, The Legal Basis of the Sexual Caste System, 5 Valpararso U. L. REv. 203 (1971). For a chart dramatizing "Castelike Status of Women and Negroes," see L. KanowrTz, supra note 15 , at 7.

${ }^{23}$ According to a recent report of the UN Secretary-General, the following six countries still deny women the rights to vote and to be elected: Jordan, Kuwait, Liechtenstein, Nigeria, Saudi Arabia, and Yemen. Implementation of the Declaration on the Elimination of Discrimination Against Women and Related Instruments, at 4, UN Doc. E/CN.6/571/Add. 2 (1973). See also Ungar, Women in the Middle East and North Africa and Universal Suffrage, $375 \mathrm{THE}$ ANNals 72 (1968).

21 For a dramatic demonstration of women's underrepresentation in all levels of governments, see UN Doc. E/CN.6/571/Add. 2, supra note 23, at 5-16. See also 11. Duverger, The Political Role of Wolien (1955); P. Lanison, Few Are Chosen: anrerucan Worren in Polittcar Life Today (1968); Menon, from Constitutional Recognition to Public Office, 375 Tre Annals 34 (1968). Cf. also Abzug, Segal, \& Kelber, Women in the Democratic Party: A Review of Affrmative Action, 6 Coluar. Hunan Rights L. Rev. 3 (1974).

" Klein, supra note 6 , at 912.

2B See L. Kanowrtz, supra note 7, at 28-31; Johnston \& Knapp, Sex Discrimination by Law: A Study in Judicial Perspective, 46 N.Y.U. L. Rev. 675, 708-21 (1971); Murnay, supra note 6, at 522; Schulder, Does the Law Oppress Women? in Sisternood Is Powerful, supra note 6 , at $139,140-41$.

Despite occasional doubts whether serving on juries is a "right, duty, or privilege" and whether exclusion of women from jury service constitutes "benign classification or invidious discrimination," it would appear that involuntary exclusion is a deprivation rather than an indulgence. Cf. K. DAvioson, R. GinsBurg, \& $\mathrm{H}$. KAy, supra note 6, at 26-35; L. KANowrT, supra note 7, at 197; L. KANowIrz, supra note 15, at 74-89.

The recent decision of Taylor v. Louisiana, 419 U.S. 522 (1975), suggests a possible trend in a different direction. Cf. also Case Comment, Twelve Good Persons and True: Healy v. Edwards and Taylor v. Louisiana, 9 Harv. Crv. Rughts-Crv. Ln. L. Rev. 561 (1974).

:7 Bradwell v. Illinois, 83 U.S. (16 Wall.) 130, 141 (1873). 
of the family" is paramount, a married woman is made to suffer a host of deprivations in the legal process. To recite Blackstone's famous dictum, marriage is a declaration of "civil death" of women. ${ }^{28}$ She is commonly required to assume her husband's name. ${ }^{29}$ Her acquisition, change, or loss of nationality is often made to depend on the marriage relationship and automatically to follow that of her husband, in disregard of her own wishes." A married woman, as Bruce has summarized, may be "unable to enter into contracts, or to sue, or be sued without the consent of her husband, or judicial authorization." ${ }^{31}$ "The wife," she adds, "may be subject to the husband's decision concerning domicile and residence without regard to her wishes or interests; and the husband's choice may affect her exercise of important legal rights which are determined by the domicile or residence of the husband." 32

The processes of government, national and local, are often employed to sustain and institutionalize discriminations against women. The "laws, institutions, and practices" simply "relegate women to an inferior status." In the United States, for example, "[ $t]$ here exist in the various States over 1,000 laws that discriminate against women." 34 In cumulative deprivation,

28 Quoted in A. Sinclatr, The Better Harf: The Emancipation of the Ametucan WOMEN 83 (1965).

${ }^{29}$ L. KanowrTz, supra note 7, at 41-46; Brown, Emerson, Falk, \& Freedman, supra note 6, at 940. Cf. also S. Ross, supra note 6, at 239-55; Carlsson, Surnames of Married Women and Legitimate Children, 17 N.Y. L. Fonum 552 (1971); Hughes, And Then There Were Two, 23 Hastings L. J. 233 (1971); Karst, "A Discrimination So Trivial:" A Note on Law and the Symbolism of Women's Dependency, 35 Orro STate L. J. 546 (1974).

30 See Unted Nations, Convention on the Nationaltry of Maruued Women,

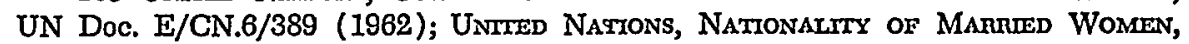
UN Doc. E/CN.6/254/Rev. I (1963); W. Waltz, The Nationality of Marnued Women (1937); McDougal, Lasswell, \& Chen, Nationality and Human Rights: The Protection of the Individual in External Arenas, 83 YALE L. J. 900, 922-23, 939-40, 973-74 (1974).

s1 Bruce, Work of the United Nations Relating to the Status of Women, 4 Human Rrgmts J. 365, 376 (1971). See also 1 W. Blackstone, Commentarues on the Laws of ENGLAND 387-92 (4th ed. J. Andrews ed. 1899).

32 Bruce, supra note 31, at 377. See also H. CLARK, The LAw of Domestic RetaTTONS 149-51 (1968); L. KaNOWITZ, supra note 7, at 46-52; UNTTED NatTons, LEGAr. Status of Marrued WoMen (Reports submitted by the Secretary-General) 8-18, UN Doc. ST/SOA/35 (1958).

33 Hearings on Equal Rights for Men and Women 1971 Before Subcomm. No. 4 of the House Comm. on the Judiciary, 92d Cong., 1st Sess., ser. 2, at 399-400 (1971) (remark of Professor Thomas I. Emerson) [hereinafter cited is House Hearings on Equal Rights]. Similarly, in the words of Kanowitz, sex-based discriminations are "supported, perpetuated and often aggravated by the organized might of domestic and foreign legal system." L. KANOwIIZ, supra note 7, at 2 .

34 Faust, Constitution Excluded Women, in House Hearing on Equal Rights, supra note 33 , at 106, 108. In the words of Jiagge: "The evidence of discrimination against women in private law provides enough material for several books to be written on the subject." Jiagge, An Introduction to the Declaration on Elimination of Discrimination Against Women, 5 UN MoNTHLY CemonICLE, 55, 58 (Mar. 1968). 
a general lack among women of access to education, skill, wealth, and other values, may handicap their participation in the effective processes of a community. ${ }^{35}$

In the field of enlightenment, denial of equal educational opportunity on account of sex is still widespread..$^{36}$ The access of women to education, especially higher education, is either denied or restricted, in comparison to that of men. Worldwide attendance by women at institutions of higher learning falls far behind that of men. ${ }^{37}$ In communities of mass illiteracy; females, especially in rural areas, typically constitute the majority of the deprived..$^{38}$ In some cultures women are still deliberately kept ignorant or encouraged in frivolity, which eases the perpetuation of male domination. $^{39}$ Despite steady progress toward coeducation, it is still a commonplace in many parts of the world that boys and girls are segregated in schools, with significantly different curricula and career orientation. ${ }^{40}$ Instead of preparing girls for "full participation in the productive life of their communities and nations," ${ }^{41}$ schooling is often conceived and made "just a preamble to marriage." ${ }^{2}$ Hence, in the words of a recent ILO report, "[g]irls are given education and training in line with traditional concepts of the role of women in society which are unrelated to the needs of today. They are often discouraged from studying subjects of importance." 43 Under the adverse influence of the inherited concepts about the respective roles of both sexes, women are deprived of opportunity to acquire, develop, and exercise a range of socially useful skills. The skills women possess

35 Cf. United Nations, 1965 Semmar on the Partictpation of Women in Public LIFE, UN Doc. ST/TAO/HR/24 (1966).

36 See C. Axmoun, Study of Discrimination in Education 29-44, UN Doc. E/ CN.4/Sub.2/181/Rev.I (1957); Beasley, Education is the Key for Women, 375 THE ANNars 154 (1968); Friderich, Access to Education at All Levels, id., at 133.

${ }^{37}$ See Klein, supra note 6, at 913; House Hearings on Equal Rights, supra note 33, at 37; K. DAvmson, R. GinsBurg, \& H. KAY, supra note 6, at 869-86.

${ }^{38}$ Study on Equal Access of Girls and Women to Literacy (Report prepared by UNESCO), UN Doc. E/CN.6/538 (1970), especially at 16; Annex II, "Mliterate population and percentage of illiteracy based on censuses or surveys since 1945 " in UN Doc. E/CN.6/538/Add.I (1970) (Annex II). Study on the Equality of Access of Girls and Women to Education in the Context of Rural Development (Report prepared by UNESCO), UN Doc. E/CN.6/566/Rev.1 (1973), especially at 27-29, 68-69. See also UN Doc. E/CN.6/566 (1973) under the latter title.

39 For a pertinent historical account, cf. generally V. BuLLOUGH, supra note 9.

40 International Labour Organization Activities of Special Interest in relation to the Employment of Women (Report by the International Labour Office), at 2-3 (Annex II), UN Doc. E/CN.6/556 (1971) [hereinafter cited as ILO Report on Women]. See also Study of Co-Education (Report prepared by UNESCO), UN Docs. E/CN.6/ 537 and Add. I (1969).

41 Study of the Interrelationship of the Status of Women and Family Planning (Report of the Special Rapporteur) 13, UN Doc. E/CN.6/575 (1973) [hereinafter cited as Report on Women and Family Planning].

42 Id. Cf. United Nations, Cruic and Political Education of Women, UN Doc. E/CN.6/405/Rev.1 (1964).

43 ILO Report on Women, supra note 40, at 3 (Annex II). 
tend to concentrate in a small number of occupations, especially in what are known as female jobs. ${ }^{44}$

In regard to well-being, the physical and mental health of women is often impaired by "the burdens of involuntary childbearing." 45 Most of the women in the world are still denied freedom to control their own fertility because of either legal or religious prohibitions or the lack of relevant information, resources, and family planning services. ${ }^{48}$ The inability to "decide freely and responsibly on the number or spacing of children (if any)" 47 has, in turn, deprived many women of benefits regarding "their health, education or employment and their roles in family and public life." 48 Sometimes women are condemned to "conditions of poverty, overwork and drudgery" ${ }^{0}$ because child and home care, in addition to childbearing, are assumed and taken to be their exclusive domain.

Discrimination against women in the wealth sector is particularly pronounced. It appears that here "[s]ex bias takes a greater economic toll than racial bias." " Under the arbitrarily rigidified division of occupations into "men's work" and "women's work," women are often confined to a narrow range of "traditionally low-paying occupations or those ranked low in prestige," ${ }^{51}$ and not permitted to penetrate "a wide range of occupations at all levels." " W2 Women are often made to "work in jobs far below their

44 International Labour Office, Fighting Discrimination in Employment and Occupation 84-94 (1968); Equal Pay for Work of Equal Value (Report by the International Labour Office) 44, UN Doc. E/CN.6/550 (1971); Report on Women and Family Planning, supra note 41, at 13; Preliminary Research Report on Working Women in the United States (Prepared under the direction of Adele Simmons for The Twentieth Century Fund Task Force on Women and Employment, 1973), reprinted in N. Donsen, N. Chachom, \& S. Law, 1973 Supplement to Volume 2, Exierson, Haber, \& Dorsen's Polrtical and Civil Rughts in the United Stattes 362-66 (1973). Cf. also Repercussions of Scientific and Technological Progress on the Conditions of Work and Employment of Women, UN Doc. E/CN.6/539 (1970); Shelton \& Berndt, Sex Discrimination in Vocational Education: Title IX and Other Remedies, 62 CAI. L. REv. 1121 (1974).

45 Report on Women and Family Planning, supra note 41, at 12.

46 Id. at 10. Cf. J. van der Tak, Abortion, Fertility, and Changing LegislaTION: AN INTERNATIONAL Review (1974).

47 Report on Women and Family Planning, supra note 41, at 10.

$48 \mathrm{Id}$. at 20.

49 Id. at 21. Cf. also Henderson, Impact of the World Social Situation on Women, 375 The ANNALs 26 (1968).

50 President's Task Force on Women's Rughts and Responsimmitres, A Matten of Simple Justice 18 (1970). See Prestoent's Commassion on the Status of Women, Report of the Commttee on Prinate Employment (1963). See also B. Babcock, A. Freedman, E. Norton, \& S. Ross, supta note 6, at 191-559; K. Davioson, R. Ginsburg, \& H. Kay, supra note 6, at 419-811; K. DeCrow, Sexist JUSTICE 64-155 (1974); UNITEd NATIONS, SEMTNAR ON THE PartTCIPATION OF WOMEN in tae Economic LIFE of ThejR Countrues, UN Doc. ST/TAO/HR/41 (1970); Johnstone, Women in Economic Life: Rights and Opportunities, 375 THE ANNALs 102 (1968); Murray, Economic and Educational Inequality Based on Sex: An Overvlew, 5 Valparaiso U. L. REv. 237 (1971).

51 Equal Pay for Work of Equal Value, supra note 44, at 44. 52 Id. 
native abilities or trained capabilities." 53 The virtually universal overrepresentation of women in the low paying jobs and their underrepresentation in the higher paying jobs, especially those of managerial character, result also in wide pay differentials between men and women. ${ }^{54}$ Even in the same employment situation, unequal pay for work of equal value generally prevails: typically women are paid at a lower rate than men. ${ }^{55} \mathrm{Job}$ advancement is usually more difficult for women than for men.

In addition to these wealth deprivations common to women in general, a married woman suffers further deprivations. Marriage often entails significant effects upon the property relations of the spouses. Financially, a married woman is commonly made to depend upon her husband, because customarily she is assigned the role of a housekeeper. Taking care of "the home, the husband and children" is a task to be performed "without financial compensation during marriage." ${ }^{6}$ Numerous restrictions, with varying degrees of severity, are widely imposed on married women's "right to acquire, administer, enjoy, dispose of and inherit property, including property acquired during [and before] the marriage." ${ }^{57}$ Thus, a married woman may be unable, without her husband's authorization or consent, to make contracts binding upon either or both of them. ${ }^{58}$ Without his authorization or consent, she may be legally incapable of undertaking an independent work, business, profession, or other occupation, outside the home. ${ }^{.9}$ She

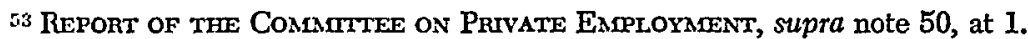

a4 See Untred Nations, Equal Pay for Equal Wonk (1960); Equal Pay for Work of Equal Value (Report by the International Labour Office), UN Doc. E/CN.6/519 (1968); Equal Pay for Work of Equal Value (Report by the International Labour Office), UN Doc. E/CN.6/550 (1971); Note, The Rights of Working Women: An International Perspective, 14 VA. J. INr'L L. 729 (1974). For studies directed to particular countries, see B. Babcock, A. Freedman, E. Norton, \& S. Ross, supra note 6, at 440-509; Beiger, Equal Pay, Equal Employment Opportunity and Equal Enforcement of the Law for Women, 5 Vaxparaiso U. L. REv. 203 (1971); Equal Pay in New Zealand, 105 INT'L Labour Rev, 569 (1972); Ireland: Interim Report on Equal Pay by the Commission on the Status of Women, id., at 182; Simchack, Equal Pay in the United States, 103 INr'L LABour REv. 541 (1971); Thalmann-Antenen, Equal Pay: The Position in Switzerland, 104 INT'L LABour REv. 275 (1971); Vangsnes, Equal Pay in Norway, 103 INT'L LABOUR REv. 379 (1971).

so See authorities cited in note 54 supra. Cf. also T. OEHMKE, Sex Discrmanation IN EMrLoyament (1974).

s. Legal Capacity of Married Women: Capacity to Engage in Independent Work (Progress Report of the Secretary-General) 4, UN Doc. E/CN.6/584 (1973).

67 Id. at 14-15. See Kahn-Freund, Matrimonial Property and Equality Before the Law: Some Sceptical Reflections, 4 Humas Righrs J. 493 (1971); Pedersen, Status of Women in Private Law, 375 The Annals 44, 47-48 (1968). Cf. also H. Sumons, African Women: Their Legal Status in South Africa 187-210 (1968).

68 L. KANowrtz, supra note 7, at 55, 197; Bradwell v. Illinois, 83 U.S. (16 Wall.) 130, 141 (1873); 1. W. BlackstoNe, supra note 31 , at 387-88. See also LEGAL Status of Mamamed WoAen, supta note 32, at 76-87.

59 See Legal Capacity of Married Women, supra note 56. This report is concerned with "[t]he capacity of wife to undertake independent work, that is, the extent to which she may freely engage in an activity of her choice, outside the home, without having to obtain her husband's authorization or consent, and the right of the wife to administer and dispose of her earnings or product of her work." Id. at 3. 
may even be required to submit her earnings to the control, management, and disposition of her husband..$^{60}$

With regard to the shaping and sharing of the affection value, the "partnership" between husband and wife is generally more "unequal" than "equal." o1 "In some parts of the world," as Justice Annie R. Jiagge, then Chairman of the Commission on the Status of Women, sharply noted, "girls under the age of ten years are given away in marriage. Young women are forced to marry men not of their choice. In some countries, consent of the woman to marriage is not a necessary legal requirement provided the consent of her parents or guardians is obtained." ${ }^{2}$ Women are often denied "autonomy and equality in decisions relating to marriage itself and choice of spouse, as well as decisions during marriage and at its dissolution." ${ }^{\text {e3 }}$ In some parts of the world, women are still victims of the practice of polygamy, especially where registration of marriages is not required.04 Many communities still confer upon the father, rather than the mother, ultimate authority in matters affecting the upbringing or education of children. ${ }^{65}$ The wife may even lack an equal voice in sexual and reproductive decisions. ${ }^{86}$ Divorce may be effected unilaterally by the husband, but not by the wife. ${ }^{67}$ The grounds and defenses available to men in proceedings for legal separation, divorce, or annulment of marriage may simply be denied to women. ${ }^{68}$ Where divorce is obtainable through mutual consent, legal safeguards may be so inadequate as to render the wife's

60 Id. at I3-17. Cf. Legar Status of Women, supra note 32, at 89-93.

61 "The ideal of marriage generally accepted in contemporary western societies and many westernized strata of developing countries is that of partnership-that is, a sharing of interests and responsibilities between husband and wife on as nearly equal basis as possible. As was with so many other ideals, practice often falls short of precept, ..." Klein, supra note 6, at 915. See also Report on Women and Family Planning, supra note 41 , at 15 . Regarding the shaping and sharing of affection, consult an important sociological study: W. GoOde, Wordd Revolution and Farimy Patrenns (1970).

B2 Jiagge, supra note 34, at 57. See also W. Goode, supra note 61, at 88-101, 104-11, 174-82, 207-18, 232-36.

63 Report on Women and Family Planning, supra note 41, at 11. See also UNITED Nations, 1961 Seminar on The Status of Women In Famexy Lafe, UN Doc. ST/ TAO/HR/11 (1961); UNITEd Nations, 1962 SEMINar on the Status of Women IN FAMITY LAW, UN Doc. ST/TAO/HR/14 (1962).

64 Report on Women and Family Planning, supra note 41, at 15; V. Burrougr, supra note 9 , at 247; W. GoodE, supra note 61 , at 101-04, 187-88, 221-25, 282-85; Pedersen, supra note 57 , at $46-47$.

65 Bruce, supra note 31, at 377. See generally Legal Status of Marrued Women, supra note 32, at 19-43; Unired Nations, Parental Rughts and DutIEs, Includnng GUARDIANSHIP (Report submitted by the Secretary-General), UN Doc. E/CN.6/474/ Rev.I (1968). ". . . the married father still plays a predominant role, especially in countries where he is considered to be the head of the family, whether explicitly or implicitly, while the married mother is relegated to a subsidiary role in this matter." United Nations, The Status of the UnMararued Mother (Report of the SecretaryGeneral) 27, UN Doc. E/CN.6/540/Rev.1 (1971).

es Report on Women and Family Planning, supra note 41, at 13.

67 Id. at 15. See W. GoODE, supra note 61, at 155-62, 262-68.

${ }^{68}$ Bruce, supra note 31 , at 377; 1962 SEMmNAR, supra note 63, at 21-26. 
consent more apparent than real. ${ }^{69}$ Widows, but not widowers, may be forbidden to remarry..$^{70}$

In the formulation and application of the norms of rectitude (responsible conduct), the most distinguishing feature is of course the prevalence of double standards. What is permissible for men is often made impermissible for women. This is most conspicuous in the area of sexual morality. Chastity may be required of women, but not of men. ${ }^{71}$ Wives may be punished for adultery, but not husbands. ${ }^{72}$ Women may be penalized for prostitution, but not their male patrons. ${ }^{73}$ Furthermore, women may be barred from participation in various religious rites and ceremonies, and denied access to the hierarchy of religious authority. ${ }^{74}$ The cumulative impact of the various deprivations, as described above, further handicaps women's capability to participate effectively and responsibly in the social process and fosters what is called the syndrome of "social marginality," such as "withdrawal, submission, inferiority, passivity." 75

\section{II.}

\section{Basic Community Policies}

The group differentiation of individuals upon the basis of sex, for the purpose of allocating access to value processes, is as inimical to the funda-

60 Id. In the words of Jiagge:

Divorce laws follow the same pattern. In some countries a man can obtain a valid divorce merely by declaring three times that he has divorced his wife. Adultery is a ground of divorce available to men in some countries but not to women. Where divorce is governed by customary rules and practices, such rules are so elastic and capable of so many interpretations that it is very easy for a man to manoeuvre and obtain a divorce on practically any ground. It is signifcant that the same facility is not available to women.

Jiagge, supra note 34 , at 57 .

70 V. Bullougr, supra note 9, at 250; W. Goode, supra note 61, at 155-62, 263-64, 376-77.

71 V. Bullougr, supra note 9 , at 45.

72 In some cultures, adultery was viewed "not a sin against morality but a trespass against the husband's property. A husband had freedom to fornicate, while a wife could be put to death for doing the same thing." V. Burlougr, supra note 9, at 23.

${ }^{73}$ Generally speaking, "prostitution is, by definition, a crime committed only by women." Brown, Emerson, Falk, \& Freedman, supra note 6, at 963. See B. BABcock, A. Freedalan, E. Norton, \& S. Ross, supra note 6, at 877-914; K. Davmson, R. Gensbung, \& H. KAY, supra note 6, at 908-10. Cf. also V. Buxxovgh, The History of Prostitution (1964).

74 "Traditionally, women have been barred from participation in many religious ceremonies, and from full participation in the hierarchies of authority. When this could not be accomplished legally, it was often accomplished by ridicule." C. ANDREAS, supra note 22, at 69 . See also D. Bateex, Tem Man-Woman Relation in Chrustian Thought (1959); M. Daiy, The Church and the Second Sex (1968); G. Harkaness, WOMEN IN ChURCH AND SOCIETY (1972).

75 Report on Women and Family Planning, supra note 41, at 9. In the same vein, Kanowitz has observed:

Discrimination, whether social or legal or both, not only stunts the personal development of its objects, causing them to become less socially productive; it also often nurtures the development of many traits and characteristics that on any objective scale would be deemed undesirable and unworthy.

L. KaNOWITZ, supra note 7, at 198-99. 
mental policies of shared respect as group differentiation based upon alleged ethnic characteristics. ${ }^{76}$ It cannot promote freedom of choice for the individual (or provide opportunity for an individual's discovering, maturing, and exercising of latent talent, either for self-fulfilment or for contribution to aggregate common interest) to allocate benefits and burdens in social process upon putative qualities of "maleness" or "femaleness" rather than upon the actual characteristics and capabilities of individual persons. Sex, no more than race, offers no rational criterion for "classification" in "determining the legal rights of women, or of men." 77 Females, no less than males, require to be treated as "persons, not statistical abstractions." 78

The justifications offered for sex-based discrimination, subordinating women, are traditionally in terms that it-is "natural or necessary or divinely ordained." 79 Sometimes it is argued that discrimination is inherent "in the divine ordinance, as well as in the nature of things." 80 At other times it is asserted that simply out of the social necessity of functional division of activities, there exists "a wide difference in the respective spheres and destinies of man and woman." 81 The "domestic sphere," it is said, "properly. belongs to the domain and functions of womanhood." ${ }^{2}$ The boldest of discriminators may on occasion argue that women are inherently inferior to men. ${ }^{83}$

It would seem peculiarly difficult, in the light of contemporary knowledge and experience, to establish that there is something "divine" or "natural" about subjecting half of the human population to the domination of the other half. Nor has it been established that such a dominationsubordination relationship is a "necessary" assignment of roles either for maximizing the fulfilment of the individual or for promoting the aggregate

${ }^{76}$ For an excellent policy exposition, see Brown, Emerson, Falk, \& Freedman, supra note 6, at 888-900. Cf. also A. Montagu, The Natural Superiontry of Wonien 204-16 (rev. ed. 1968).

${ }^{77}$ Brown, Emerson, Falk, \& Freedman, supra note 6, at 889 . In the words of Montagu:

Human beings differ greatly in their abilities but practically not at all along sex lines; that is to say, abilities are not determined by sex. Abilities are functions of persons, not of groups or classes. Hence, so far as abilities are concerned both sexes should be afforded equal opportunities to realize their potentialities, and the judgment of their abilities should not be prejudiced by any bias of sex.

A. Montagu, supra note 76, at 208.

78 Brown, Emerson, Falk, \& Freedman, supra note 6, at 889.

$79 \mathrm{Id}$. at 872 .

80 Bradwell v. Tllinois, 83 U.S. (16 Wall.) 130, 141 (1873).

81 Id.

$82 \mathrm{Id}$.

${ }^{83} \mathrm{See}$ authorities cited in notes 20 and 22 supra. For a strong attack upon the myth of women's inferiority, see A. MoNTAGU, supra note 76. Montagu writes:

The natural superiority of women is a biological fact, and a socially overlooked piece of knowledge. The facts have been avaiJable for half a century, but in a male-dominated world, in which the inflation of the male ego has been dependent upon the preservation of the myth of male superiority, their significance has escaped the attention merited. When the history of the subject comes to be written, this peculiar omission will no doubt serve as yet another forcible illustration that we see only what and how we want to see.

Id. at 205. 
common interest. Indeed, all contemporary knowledge and experience would appear to confirm the opposite.

In a global community aspiring towards human dignity, a basic policy should, accordingly, be to make the social roles of the two sexes, with the notable exception of childbearing, as nearly interchangeable or equivalent as possible. ${ }^{84}$ To achieve genuine equality between the sexes, it is vital that "nobody be forced into a predetermined role on account of sex, but each person be given better possibilities to develop his or her personal talents." ${ }^{85}$ Such a policy need not of course preclude separate consideration of matters arising from "a physical characteristic unique to one sex." so "So long," write recent infuential authors, "as the law deals only with a characteristic found in all (or some) women but in no men, or in all (or some) men but no women, it does not ignore individual characteristics found in both sexes in favor of an average based on one sex." ${ }^{87}$

In sum, the most rational general community policy requires the complete emancipation of women, without countenancing the subordination of men. John Stuart Mill affirmed a mature opinion, still relevant:

That the principle which regulates the existing social relations between the two sexes-the legal subordination of one sex to the other-is wrong in itself, and now one of the chief hindrances to human improvement; and that it ought to be replaced by a principle of perfect equality, admitting no power or privilege on the one side, nor disability on the other..$^{88}$

\section{III.}

\section{Trends in Prescription}

The drive toward eradication of sex-based discrimination, like that designed to eliminate racial discrimnation, has in recent decades been a vital component of the trend toward a more general norm of nondiscrimination. The commurity concern for the protection of women, antedating the broader United Nations attack upon discrimination, was evident in certain significant areas at the turn of the twentieth century. Thus, in 1902, the Hague Conventions dealt with conflicts of national laws concerning marriage, divorce, and the guardianship of minors. ${ }^{89}$ In 1904 and 1910, con-

84 From a biological viewpoint, the different parts men and women play in the reproductive function undoubtedly contribute to sex differentiation in psychological development. Thus the long period of child bearing and child rearing, which falls biologically upon the female, has far-reaching implications for sex differences in interests, attitudes, emotional traits, vocational goals, and achievement.

Anastasi, Individual Differences: Overview, 7 INT'L ENCYc. Soc. Sc. 200, 205 (1968). Cf. also Tyler, Individual Differences: Sex Differences, id. at 207.

s5 Ginsburg, The Status of Women: Introduction, 20 Am. J. Comp. I. 585, 589 (1972).

86 Brown, Emerson, Falk, \& Friedman, supra note 6, at 893.

$87 \mathrm{Id}$.

ss Mill, The Subjection of Women, in Essays on Sex Equalrty: John Stuant MuL \& Harruet Taylor Minl 123, 125 (A. Rossi ed. 1970).

89 United Nations, The Untted Nations and the Status of Women 3 (1964). 
ventions were adopted to combat traffic in women.90 The Covenant of the League of Nations represented an important development, calling for humane working conditions for all, irrespective of sex, and for the suppression of traffic in women.12 Thus, employment in the League Secretariat was freed from discrimination. Article 7(3) of the Covenant of the League provided: "All positions under or in connection with the League, including the Secretariat, shall be open equally to men and women." In 1937, the League appointed an expert committee to undertake a comprehensive study on the legal status of women, the work of which was unfortunately interrupted by the outbreak of World War II. The International Labour Organization, an "autonomous partner" ${ }^{22}$ of the League established in 1919, has continuously sought to achieve humane working conditions for all, irrespective of sex. In 1944, the purposes of ILO, as originally contained in the Preamble to its Constitution and Article 427 of the Treaty of Versailles, were emphatically restated in the Declaration of Philadelphia:

[A]ll human beings, irrespective of race, creed or sex, have the right to pursue both their material well-being and their spiritual development in conditions of freedom and dignity, of economic security and equal opportunity. ${ }^{94}$

An impressive regional effort to protect women in Latin America has been spearheaded since 1928 by the Inter-American Commission of Women. ${ }^{05}$

The contemporary broad prescription against sex-based discrimination has its origins in the United Nations Charter and in various ancillary expressions and commitments. The more important general prohibitions of discrimination explicitly and consistently specify sex as among the impermissible grounds of differentiation. The United Nations Charter, after reaffirming in the Preamble "faith in fundamental human rights, in the dignity and worth of the human person, in the equal rights of men and women," pronounces in Article 1(3) that one of its purposes is to promote and encourage "respect for human rights and for fundamental freedoms for all without distinction" on account of sex or other grounds. This theme is

so International Agreement for the Suppression of the White Slave Traffic, signed at Paris on 18 May 1904, entered into force on 18 July 1905. For its text, see 1 LNTS 83. International Convention for the Suppression of the White Slave Traffic, signed at Paris 4 May 1910, Great Brttand, Treaty Serues No. 20 (1912). For subsequent amendments of these two treaties in 1949 through protocols, see 30 UNTS 23, 92 UNTS 19, 98 UNTS 101. For further details, consult UNITED Natrons, MuLruidTERAr Treattes in Respect of Which the Secretary-General Performs Depositony Functions: List of Stgnatures, Ratifications, Accessions, etc. as at 31 December 1972, at 168-74, UN Doc. ST/LEG/SER.D/6 (1973) [hereinafter cited as MurTIlateral Treaties, 1972]. See also United Nations, Studx on Traftic in Pensons AND Prostiturion, UN Doc. ST/SOA/SD/8 (1959).

81 The Covenant of the League of Nations, Art. 23(a) and (c).

92 1 L. Oppenhenc, INTERnational LaW 717 (H. Lauterpacht ed. 8th ed. 1955).

${ }^{83}$ Treaty of Versailles, June 28, 1919, 2 Majon Peace Treaties of Modern Histony, 1648-1967, at 1265, 1522-23 (F. Israel ed. 1967).

94 2 International Governmental Organzattons: Constrtutional Documents 1246, 1247 (A. Peaslee ed. rev. 2d ed. 1961). (Italics added).

${ }^{95}$ See authorities cited in notes 218-27 infra and accompanying text. 
given further concrete expression in such provisions as Articles $13(1)(b)$, $55(\mathrm{c}), 56,62(2)$, and $76(\mathrm{c}) .^{96}$ Of particular significance is Article 8 which reads:

The United Nations shall place no restrictions on the eligibility of men and women to participate in any capacity and under conditions of equality in its principal and subsidiary organs. ${ }^{27}$

The Universal Declaration of Human Rights, in setting forth "the civil and political rights and the economic, social and cultural rights to which every individual-man or woman-is entitled," ${ }^{88}$ has inspired, as in other areas, much of the contemporary activity for the protection of women. In its broad formulation of the general norm of nondiscrimination, Article 2 of the Universal Declaration specifies "sex" as among the impermissible grounds of differentiation, ${ }^{99}$ a provision further reinforced by the equal

${ }^{96}$ Article $13(1)(b)$ reads:

The General Assembly shall initiate studies and make recommendations for the purpose of:

b. promoting international co-operation in the economic, social, cultural, educational, and health fields, and assisting in the realization of human rights and fundamental freedoms for all without distinction as to race, sex, language, or religion.

Article 55(c) provides:

With a view to the creation of conditions of stability and well-being which are necessary for peaceful and friendly relations among nations based on respect for the principle of equal rights and self-determination of peoples, the United Nations shall promote:

c. universal respect for, and observance of, human rights and fundamental freedoms for all without distinction as to race, sex, language, or religion.

Article 56 stipulates:

All Members pledge thenaselves to take joint and separate action in co-operation with the Organization for the achievement of the purposes set forth in Article 55 .

Article 62(2) states:

It [the Economic and Social Council] may make recommendations for the purpose of promoting respect for, and observance of, human rights and fundamental freedoms for all.

Article 76(c) reads:

The basic objectives of the trusteeship system, in accordance with the Purposes of the United Nations laid down in Article $I$ of the present Charter, shall be:

$\dot{c}$. to encourage respect for human rights and for fundamental freedoms for all without distinction as to race, sex, language, or religion, and to encourage recognition of the interdependence of the peoples of the world; ...

${ }^{07}$ However, for a dramatic demonstration of women's underrepresentation in the higher positions within the United Nations, see K. Davmson, R. GinsBurg, \& H. KAY, supra note 6, at 932-34. See also Szalai, The Situation of Women in the United Nations, UNITAR Research Report No. 18 (1973); Differential Treatment Based upon Sex under the Staff Regulations and Staff Rules (Report of the Secretary-General), UN Doc. A/C.5/1519 (1973).

98 Bruce, supra note 31 , at 369-70.

90 Article 2 reads in part: "Everyone is entitled to all the rights and freedoms set forth in this Declaration, without distinction of any kind, such as race, colour, sex, language, religion, political or other opinion, national or social origin, property, birth or other status." UNITED Nations, Human Rights: A CoMpPIATION OF INTERnationar INSTRUMIENTS OF THE UNTED NATTONS 1, UN Doc. ST/HR/I (1973) [hereinafter cited as UN HuMgan Rughts INSTRUMENTS]. 
protection clause of Article 7. ${ }^{100}$ The two International Covenants on Human Rights, incorporating and reinforcing the general norm of nondiscrimination enunciated in the Universal Declaration, emphatically forbid discrimination on account of sex. Significantly, each of the two Covenants contains, in practically identical terms, a special article on the equality of sexes. The International Covenant on Civil and Political Rights, in Article 3 , provides:

The States Parties to the present Covenant undertake to ensure the equal right of men and women to the enjoyment of all civil and political rights set forth in the present Covenant. ${ }^{101}$

Similarly, Article 3 of the International Covenant on Economic, Social and Cultural Rights reads:

The States Parties to the present Covenant undertake to ensure the equal right of men and women to the enjoyment of all economic, social and cultural rights set forth in the present Covenant. ${ }^{102}$

These separate articles are in addition to other pertinent nondiscrimination provisions which include "sex," along with race and other factors, among the prohibited grounds of differentiation. ${ }^{103}$

The general norm against sex-based discrimination, thus formulated and established, is further illustrated and reinforced by a number of conventions and other authoritative expressions oriented toward the protection of women against particular vulnerabilities or in regard to particular

100 Article 7 reads:

All are equal before the law and are entitled without any discrimination to equal protection of the law. All are entitled to equal protection against any discrimination in violation of this Declaration and against any incitement to such discrimi-

Id. nation.

$101 \mathrm{Id}$. at 8.

$102 \mathrm{Id}$. at 4 .

${ }^{103}$ The International Covenant on Civil and Political Rights provides in Article 2(1) that

Each State Party to the present Covenant undertakes to respect and to ensure to all individuals within its territory and subject to its jurisdiction the rights recognized in the present Covenant, without distinction of any kind, such as race, colour, sex, language, religion, political or other opinion, national or social origin, property, birth or other status;

and adds, in Article 26, that

All persons are equal before the law and are entitled without any discrimination to the equal protection of the law. In this respect, the law shall prohibit any discrimination and guarantee to all persons equal and effective protection against discrimination on any ground such as race, colour, sex, language, religion, political or other opinion, national or social origin, property, birth or other status.

Id. at 8,11 .

Similarly, the International Covenant on Economic, Social, and Cultural Rights provides in Article 2(2) that

The States Parties to the present Covenant undertake to guarantee that the rights enunciated in the present Covenant will be exercised without discrimination of any kind as to race, colour, sex, language, religion, political or other opinion, national or social origin, property, birth or other status.

Id. at 4 .

For further elaboration, see McDougal, Lasswell, \& Chen, supra note 4. 
values. ${ }^{104}$ Thus, in 1951, the Equal Remuneration Convention was adopted by the International Labour Organization to put into effect "the principle of equal remuneration for men and women workers for work of equal value." 105 Now operative in some 70 countries, this Convention substantially increases the protection of women in relation to wealth processes. According to Article 1, the term "equal remuneration for men and women workers for work of equal value" refers to "rates of remuneration established without discrimination based on sex," 100 while "remuneration" embraces "the ordinary, basic or minimum wage or salary and any additional emoluments whatsoever payable directly or indirectly, whether in cash or in kind, by the employer to the worker and arising out of the workers' employment." ${ }^{107}$ The Convention, in Article 2(1), obliges each ratifying member to "promote" and, "in so far as is consistent with" "the methods in operation for determining rates of remuneration," "ensure the application to all workers of the principle of equal remuneration for men and women workers for work of equal value." 108 The term "the methods in operation for determining rates of remuneration" was understood to mean not "the principles on which wage and salary structures are currently based" but "the procedures applicable in accordance with national law or practice for the purpose of fixing or settling wages and salaries in the various trades, industries or professions." ${ }^{109}$ The Convention further stipulates in Article $2(2)$, with a flexibility appropriate for different communities, that the principle of equal remuneration may be applied by means of:

(a) National laws or regulations;

(b) Legally established or recognized machinery for wage determination;

(c) Collective agreements between employers and workers; or

(d) A combination of these various means.110

"Where such action will assist," Article 3(1) indicates, "in giving effect to the provisions" of the Convention, "measures shall be taken to promote objective appraisal of jobs on the basis of the work to be performed." 111 "Differential rates between workers which correspond, without regard to sex, to differences as determined by such objective appraisal in the work to be performed" are, according to Article 3(3), "not" to be considered contrary to the principle of equal remuneration. ${ }^{112}$

Of especial importance in relation to both formal and effective power is the Convention on the Political Rights of Women, adopted by the General Assembly of the United Nations in 1952, which seeks, in implementation of

104 For an overview, consult Study of Provisions in Existing Conventions that Relate to the Status of Women: Report of the Secretary-General, UN Doc. E/CN.6/552 (1972). See also The United Nations and the Advancement of Women (Study prepared by Mrs. M. K. Baxter), UN Doc. A/CONF.32/L.7 (1968).

105 UN HuncaN Rigrts INstrungeNTs, supta note 99, at 37 (preamble).

103 UN Huaran Rights Instrunients, supra note 99 , at 37.

107 Id. $108 \mathrm{Id}$.

100 C. Jenks, Hudan Rughts and International Labour Standards 92 (1960).

110 UN HUMAN Rights INSTRUNENTs, supra note 99 , at 37.

111 Id. 112 Id. 
"the principle of equality of rights for men and women contained in the Charter of the United Nations," to "equalize the status of men and women in the enjoyment and exercise of political rights." 113 This Convention reflected the widespread recognition that "the achievement of full status for women as citizens was the key to acceptance of women as equal participants in the life of the community." 114 "This Convention," in the words of a UN study, "is not just another treaty prepared under the auspices of an international organization-it is the first instrument of international law aiming at the granting and at the protection of women's rights on a worldwide basis." 115 The Convention declares, in Article 1, that

Women shall be entitled to vote in all elections on equal terms with men, without any discrimination; ${ }^{116}$

and, in Article 2, that

Women shall be eligible for election to all publicly elected bodies, established by national law, on equal terms with men, without any discrimination. ${ }^{117}$

The broad reach toward voting in "all elections" and eligibility for election to "all publicly elected bodies" has obvious consequences for equality in effective power. Beyond opportunity for elective office, the Convention further affords women equal access to all appointive public posts. Article 3 reads:

Women shall be entitled to hold public office and to exercise all public functions, established by national law, on equal terms with men, without any discrimination. ${ }^{118}$

The term "public office," as the U.S. representative emphasized before the Third Committee of the General Assembly, was meant to include "posts in the civil service, the foreign or diplomatic service and the judiciary branch, as well as to posts which were primarily political in nature. The number of such posts established by national law was usually large and the tasks to be performed varied widely." 110 The phrase "on equal terms with men," the representative added, "covered such questions as recruitment, exemptions, salary, old-age and retirement benefits, opportunities

113 Id. at 90 (preamble). Its text is printed in 193 UNTS 135. Operative since July 7, 1954, the Convention on the Political Rights of Women had, as of December 31,1972 , been ratified, or acceded to, by 69 states. Multilateral Trenties, 1072, supra note 90 , at $349-50$.

114 Untred Nations, The Convention on tae Poltitcal Rights of Women: History AND COMMENTARY 1, UN Doc. ST/SOA/27 (1955). Cf. also E. FLEXNER, Century of Struggle: THE Woman's Rights Movement in the Untred States (1959); Untred Nations, The Road to Equality: Polmtical Rights of Women, UN Doc. ST/SOA/13 (1953); Political Rights of Women (Report of the SecretaryGeneral), UN Doc. A/8481 (1971).

115 The Convention on the Poltical Rugets of Women, supra note 114, at v.

116 UN HUMAN Rughts INSTRUMENTS, supra note 99, at 90.

117 Id. 118 Id.

119 GAOR, 7th Sess., 3rd Comm. 341 (1952). 
for promotion, and employment of married women, all of which were important matters in which women had sought equality for many years." 120

In 1957, the Convention on the Nationality of Married Women, adopted by the General Assembly in recognition that "conflicts in law and in practice with reference to nationality arise as a result of provisions concerning the loss or acquisition of nationality by women as a result of marriage, of its dissolution or of the change of nationality by the husband during marriage," ${ }^{121}$ sought to remedy a special inequity often imposed upon married women. This Convention is designed to "eliminate the automatic effect on the nationality of the wife of marriage, its dissolution, or the change of nationality by the husband" and to "provide a satisfactory solution to the conflicts of law regarding the effect of marriage on the nationality of the wife." 122 The principal thrust of the Convention is to establish, in the crucial matter of married women's nationality, the principle of equality between the sexes, in discard of the anachronistic doctrine of "the unity of family" as "headed by the husband." ${ }^{123}$ The Convention, going beyond such existing prescriptions as embodied in the 1930 Hague Convention on Certain Questions relating to the Conflict of Nationality Laws, ${ }^{124}$ stipulates emphatically in Article 1 that

neither the celebration nor the dissolution of a marriage between one of its nationals and an alien, nor the change of nationality by the husband during marriage, shall automatically affect the nationality of the wife; ${ }^{125}$

and, in Article 2, that

neither the voluntary acquisition of the nationality of another State nor the renunciation of its nationality by one of its nationals shall prevent the retention of its nationality by the wife of such national..$^{126}$

The Convention further provides in Article 3 that "specially privileged naturalization procedures" be made available for a wife who wishes to acquire the nationality of her husband. ${ }^{227}$

In striking at another deprivation of broad concern, the 1958 Discrimination (Employment and Occupation) Convention prohibits in Article 1 (1) (a) "any distinction, exclusion or preference" on account of sex, along with race and other grounds, which "has the effect of nullifying or impair-

$120 I d$.

121 UN Hunan Rights INSTRUMeNTs, supra note 99, at 56. Its text is in 309 UNTS 65. Entering into effect since August 11, 1958, the Convention, as of December 31, 1972 , had been ratified, or acceded to, by 44 states. Multrlateral Treaties, 1972, supra note 90 , at $356-58$.

122 United Nations, Convention on the Nationality of Married Women: Historucar Background and Conmentary 25, UN Doc. E/CN.6/389 (1962).

123 See id. at 30-33; United Nations, Natronality of Marqued Women 8-18, UN Doc. E/CN.6/254/Rev.1 (1963).

124179 LNTS 89, 101 (Art. 8). See McDougal, Lasswell, \& Chen, supra note 30, at $973-74$.

${ }_{125}$ UN HuAlaN Rughts INSTRuaients, supra note 99, at 56.

$1201 d$.

127 Id. 
ing equality of opportunity or treatment in employment or occupation." 128 The terms "employment" and "occupation," Article 1(3) adds, include "access to vocational training, access to employment and to particular occupations, and terms and conditions of employment." 120

Similarly, the 1960 Convention against Discrimination in Education prohibits, pursuant to Article 1(1), "any distinction, exclusion, limitation or preference," on account of sex, among others, which "has the purpose or effect of nullifying or impairing equality of treatment in education." 130 The term "education," Article I(2) immediately adds, "refers to all types and levels of education, and includes access to education, the standard and quality of education, and the conditions under which it is given." ${ }^{131}$

In 1962, the Convention on Consent to Marriage, Minimum Age for Marriage and Registration of Marriages was adopted by the General Assembly seeking to ensure, in substance, "equal rights" of women and men "as to marriage, during marriage and at its dissolution" by virtue of "the principle of free consent to marriage" and prohibition of child marriages. ${ }^{132}$ The Convention stipulates in Article 1(1) that "[n]o marriage shall be legally entered into without the full and free consent of both parties" and "such consent" is to be "expressed by them in person after due publicity and in the presence of the authority competent to solemnize the marriage and of witnesses, as prescribed by law." ${ }^{133}$ Article 2 obliges contracting states to "take legislative action to specify a minimum age for marriage", though it is left to each individual state to decide that particular age. ${ }^{134}$ In Article 3 , the Convention further requires that "all marriages" be "registered in an appropriate official register by the competent authority." ${ }^{180}$ This Convention is further strengthened and supplemented by the recommendation on the same subject adopted by the General Assembly in November, 1965. ${ }^{136}$ Instead of indulging the discretion of a contracting state, the recommendation specifies that the minimum age of marriage not be lower than "fifteen years of age." 137

128 Id. at 29.

${ }^{129}$ Id. Cf. also International Labour Organization Activities of Special Interest in Relation to the Employment of Women, UN Doc. E/CN.6/579 (1973).

130 UN HUMAN Rughts INSTRUMENTS, supra note 99, at 31.

131 Id. "The establishment or maintenance of separate educational systems or institutions for pupils of the two sexes" would not be barred, provided that, pursuant to Article 2(a), "these systems or institutions offer equivalent access to education, provide a teaching staff with qualifications of the same standard as well as school premises and equipment of the same quality, and afford the opportunity to take the same or equivalent courses of study."

132 Bruce, supra note 31 , at 375 . For the text of the Convention, see 521 UNTS 231; UN HUMAN Rigers INstrumEnTs, supra note 99, at 92. In operation since December 9, 1964, the Convention, as of December 31, 1972, had been ratified, or acceded to, by 26 states. Murrilateral. Treaties, 1972, supra note 90, at 359-60.

133 UN HUMLAN RighTs InstruMENTs, supra note 99, at 92.

$134 \mathrm{Id}$. $135 \mathrm{Id}$.

138 GA Res. 2018, GAOR, 20th Sess., Supp. 14, at 36, UN Doc. A/6014 (1965). The text of the resolution is reprinted in UN HUMAN Rugrrs INstruments, supra note 99 , at 93-94.

137 UN Human Rigers Instruments, supra note 99, at 93 (Principle II). 
The basic framework in which community expectations against sex-based discrimination are crystallizing is indicated in the 1967 Declaration on the Elimination of Discrimination against Women ${ }^{138}$ and in the Draft Convention on the Elimination of All Forms of Discrimination against Women, currently under consideration by the Commission on the Status of Women. ${ }^{139}$ The Declaration, unanimously adopted by the General Assembly on November 7, 1967, as described by a UN statement, "marks the culmination of efforts by the United Nations and by other organs, including nongovernmental organizations, to formulate the principles of equal rights for women." ${ }^{140}$ The Draft Convention is a consequence of a decision by the Commission on the Status of Women, at its twenty-fifth session in January, 1974, that "a single comprehensive draft convention should be prepared, without prejudice to the preparation of any future instrument or instruments which might be elaborated either by the United Nations or by the specialized agencies dealing with discrimination in specific fields." ${ }^{141}$ The draft prepared by the Commission's Working Group is being forwarded to member governments for study and comments and the item "Consideration of a draft convention on the elimination of discrimination against women" will be accorded top priority at the Commission's twenty-sixth session in 1975, the year designated as "International Women's Year." 142 Whatever

138 GA Res. 2263, GAOR, 22nd Sess., Supp. 16, at 35, UN Doc. A/6716 (1967). The text is reprinted in UN HUMan RuGHTs INSTRUMIENTs, supra note 99, at 39-40.

139 Comansston on the Status of Women, Report on the Twenty-Fifth Sesston, ECOSOC, 56th Sess., Supp. 4, at 28-46, 83-84, UN Doc. E/5451(E/CN.6/589) (1974) [hereinafter cited as 1974 REPORT OF THE CoManssion on taE STATUS OF WOMEN].

${ }^{140}$ Declaration on the Elimination of Discrimination against Women, 4 UN MONTHLY Chronicle 113 (Dec. 1967). In 1963, the General Assembly, by a unanimous resolution, took the initiative in calling for the preparation of a Declaration on the elimination of discrimination against women. The Assembly instructed the Commission on the Status of Women to prepare a draft and invited member governments, the specialized agencies, and appropriate nongovernmental organizations to submit proposals for incorporation into the draft. In 1966, the General Assembly, upon receipt of the Commission's draft, decided to return it to the Commission for further work, with instructions that the suggestions made by various governments and other bodies be taken into account. The task of drafting and redrafting, though not without diffculty, came to fruition after the revised draft, completed in March 1967 by the Commission, was considered by the Assembly's Third Committee in October, and later unanimously approved by the General Assembly on November 7, 1967.

On the legislative history of the Declaration, see EQUar RigerTs for Women, supra note 11; Draft Declaration on the Elimination of Discrimination against Women: Note by the Secretary-General, UN Doc. A/6678 (1967); also under the same title, UN Doc. A/6349 (1966); [1967] YEArbook of THE UNTTED NATIONS 513-14, 518-22 [hereinafter cited as YBUN]; [1966] YBUN 462-63, 466-68.

1411974 Report of the Conartsston on the Status of WOMEn, supra note 139, at 31. See also 11 UN Montrul Chronicle 26 (Feb. 1974). For the pros and cons of formulating a single comprehensive convention, see Consideration of Proposals concerning a New Instrument or Instruments of International Law to Eliminate Discrimination against Women, UN Doc. E/CN.6/573 (1973).

14: Conmission Res. 1 (XXV) adopted at the 618th meeting, January 25, 1974, 1974 REpont of the Conmussion on the Status of WoMeN, supra note 139, at 83-84. ".. . the proposed draft Convention was broader in scope than the Declaration but, at the same time included only fundamental aspects of women's rights and 
final form this Convention may take, its substantive content is not likely. to vary greatly from that of the version presently before the Commission.

Underscoring in its preamble the imperative need to "ensure the universal recognition in law and in fact of the principle of equality of men and women," ${ }^{143}$ the Declaration stresses that

discrimination against women is incompatible with human dignity and with the welfare of the family and of society, prevents their participation, on equal terms with men, in the political, social, economic and cultural life of their countries and is an obstacle to the full development of the potentialities of women in the service of their countries and of humanity; ${ }^{144}$

and that

the full and complete development of a country, the welfare of the world and the cause of peace require the maximum participation of women as well as men in all fields..$^{145}$

The same theme is carried forward in the Draft Convention. ${ }^{240}$

The Declaration and the Draft Convention, drawing heavily upon the parallel formulations in relation to racial discrimination, ${ }^{147}$ spell out in both broad and detailed terms the basic norm against discrimination, the commitment to effect necessary changes in both authoritative and effective power processes within national communities, and the content of prescription in relation to various critical sectors where women most require protection. The Declaration states the basic norm of nondiscrimination in Article 1:

Discrimination against women, denying or limiting as it does their equality of rights with men, is fundamentally unjust and constitutes an offence against human dignity..$^{148}$

The Draft Convention in its first article adds further content to the concept of discrimination:

In this Convention the term "discrimination against women" shall mean any distinction, exclusion or restriction made on the basis of sex

avoided detailed and specific provisions which were already embodied in the International Labour Organization and UNESCO Conventions." Consideration of Proposals Concerning a New Instrument or Instruments of International Law to Eliminate Discrimination Against Women (Report of the Working Group to the Commission on the Status of Women) 4, UN Doc. E/CN.6/574 (1974) [hereinafter cited as Report of the Working Group].

143 UN HUMAN Rigets Instruments, supra note 99, at 39.

144 Id. $145 \mathrm{Id}$.

148 I974 Report of the Comamassion on the Status of Women, supta noto 139, at $32-34$.

${ }^{147}$ The reference is to United Nations Declaration on the Elimination of All Forms of Racial Discrimination, GA Res. 1904, GAOR, 18th Sess., Supp. 15, at 35, UN Doc. A/5515 (1963), and to International Convention on the Elimination of All Forms of Racial Discrimination, GA Res. 2106A, GAOR, 20th Sess., Supp. 14, at 47, UN Doc. A/6014 (1965). The text of these two documents is reprinted in UN HuMan Rugrrs INSTRUMENTs, supra note 99 , at 22 and 23 respectively. For a detailed analysis, with pertinent references, see McDougal, Lasswell, \& Chen, supra note 4.

148 UN Human Rughts Instruments, supra note 99, at 39. 
which has the effect of or the purpose of nullifying the recognition, enjoyment or exercise of human rights and fundamental freedoms in the political, economic, social, cultural or any field of public life.149

This formulation, evidently adopted from Article $1(1)$ of the Convention on the Elimination of Racial Discrimination, ${ }^{150}$ would appear to encompass at least as broad a prohibition. ${ }^{151}$ As a means of expediting necessary changes in the processes of authoritative decision within national communities, the Declaration stipulates in Article 2:

All appropriate measures shall be taken to abolish existing laws, customs, regulations and practices which are discriminatory against women, and to establish adequate legal protection for equal rights of men and women, in particular:

(a) The principle of equality of rights shall be embodied in the constitution or otherwise guaranteed by law;

(b) The international instruments of the United Nations and the specialized agencies relating to the elimination of discrimination against women shall be ratified or acceded to and fully implemented as soon as practicable. ${ }^{152}$

This stipulation entails positive as well as negative formulations. Negatively, all "existing laws, customs, regulations and practices" discriminatory against women are to be abolished. Positively, "adequate legal protection for equal rights of men and women" is to be established so that in all important sectors of community life women may fully develop their potentials equally and contribute to aggregate common interest. In the course of drafting, both in the Commission and in the General Assembly, strong arguments were made in the debate against the inclusion in this provision of "customs" and "practices," along with "laws" and "regulations," on the grounds that "customs based on long-standing traditions could not be abolished overnight"; ${ }^{153}$ it would be more appropriate, according to this view, gradually to "modify" or "change" rather than "abolish," customs and practices. ${ }^{154}$ The majority, in rejecting this view, "held it necessary to call for abolishing discriminatory customs and practices precisely because that was the very purpose of the Declaration." ${ }^{155}$

The Draft Convention, in addition to reiterating this broad stipulation, obliges in Article 2(b) and (c) a contracting state to engage in "no act 34.

1*0 1974 Report of the Conamssion on the Status of Women, supra note 139, at

${ }^{150}$ It may be recalled that Article $1(1)$ of the International Convention on the Elimination of All Forms of Racial Discrimination reads as follows:

In this Convention, the term "racial discrimination" shall mean any distinction, exclusion, restriction or preference based on race, colour, descent, or national or ethnic origin which has the purpose or effect of nullifying or impairing the recognition, enjoyment or exercise, on an equal footing, of human rights and fundamental freedoms in the political, economic, social, cultural or any other field of public life.

UN HURIAN Rugets INSTRUMENTs, supta note 99, at 24.

${ }_{151}$ Cf. McDougal, Lasswell, \& Chen, supra note 4.

152 UN HUMAN RIGETS INSTRUNIENTS, supra note 99, at 39.

153 EQUAr. RugHTS For Women, supra note 11, at 3.

154 Id.

155 Id. 
or practice of discrimination against women and to ensure that public authorities and public institutions, national and local, shall act in conformity with this obligation," 156 and "not to sponsor, defend or support discrimination against women by any person or organizations." 107 The Draft Convention further proposes in Article 5(2) to prohibit by law "[a]ny advocacy of the superiority of one sex over the other and of discrimination on the basis of sex." 158

In attempting to promote necessary changes in effective power processes, special attention is directed to the long-range goals of prevention and reconstruction. Particular emphasis is put upon changing stereotyped community predispositions about the role of women and upon cultivating sounder perspectives that define appropriate roles for both women and men in the contemporary world. Thus, Article 3 of the Declaration reads:

All appropriate measures shall be taken to educate public opinion and to direct national aspirations towards the eradication of prejudice and the abolition of customary and all other practices which are based on the idea of the inferiority of women. ${ }^{150}$

The Draft Convention adds a new dimension in Article 5(1) by asserting that "the protection of motherhood is a common interest of the entire society which should bear responsibilities for it." ${ }^{160}$ The bringing up of new generations is at last acknowledged as an ongoing enterprise for the whole community.

Both the Declaration and the Draft Convention spotlight certain critical areas in which women are particularly susceptible to deprivation. Amplifying some of the prior conventions which have been noted above, ${ }^{102}$ they offer detailed specification of a range of protected rights, embracing all important value sectors, notably power, enlightenment, wealth, wellbeing, and affection.

In reference to power, the Declaration stresses the equal rights of women in regard to nationality, legal capacity, freedom of movement, and voting and officeholding (elective and appointive alike). Thus, Article 4 of the Declaration states:

All appropriate measures shall be taken to ensure to women on equal terms with men, without any discrimination:

(a) The right to vote in all elections and be eligible for election to all publicly elected bodies;

(b) The right to vote in all public referenda;

(c) The right to hold public office and to exercise all public functions.

Such rights shall be guaranteed by legislation. ${ }^{\mathbf{1 0 2}}$

1561974 Repont of the Conmission on the Status of WOMEN, supra note 139, at 34-35.

157 Id. at 35 .

$158 \mathrm{Id}$. at 36.

159 UN HumaN Rights Instrumeints, supra note 99, at 39.

1601974 Report of the Comarission on the Status of Women, supra note 139, at 36.

101 See text and the accompanying notes 104-37 supra.

162 UN HUMAN Righrs Instrunments, supra note 99, at 39. 
The specification of an equal right to vote "in all public referenda," as indicated in paragraph $b$, is a novel feature, not included in the 1952 Convention on the Political Rights of Women. ${ }^{163}$ The Draft Convention seeks in Article 8 to broaden and fortify this provision by urging that "all appropriate measures" be taken to "ensure to women on equal terms with men, without any discrimination, equal opportunities to participate in the political and public life of the country." ${ }^{164}$ In illustration, the Draft Convention further underscores "equal opportunities" to "participate in the formulation of government policy and the administration thereof and to hold public office at the national and local levels" ${ }^{165}$ and to "participate in nongovernmental organizations and associations." 166

In the matter of nationality, the Declaration and the Draft Convention seek to protect women from the bondage and hardships caused by involuntary acquisition, change, and retention of nationality, which automatically result from marriage to an alien husband. ${ }^{167}$ Article 5 of the Declaration reads:

Women shall have the same rights as men to acquire, change or retain their nationality. Marriage to an alien shall not automatically affect the nationality of the wife either by rendering her stateless or by forcing upon her the nationality of her husband.108

Drawing upon the 1957 Convention on the Nationality of Married Women, ${ }^{109}$ the Draft Convention is more detailed in its formulation. Article 9 (1) reads:

States Parties shall grant women the same rights as men to acquire, change or retain their nationality and shall require, in particular, that neither marriage of a woman to, nor dissolution of her marriage from, an alien nor the change of nationality by her alien husband during marriage shall automatically change her nationality, render her stateless or force upon her the nationality of her husband.170

The second paragraph of this article urges the grant of nationality to alien women married to nationals "through specially privileged naturalization procedures," ${ }^{171}$ as distinguished from those ordinarily applicable to aliens in general.

In further reference to shared power, the Declaration, in Article 6(1) (b) and (c), stipulates that "all appropriate measures, particularly legislative measures," be taken to "ensure to women, married or unmarried," the "right to equality in legal capacity and the exercise thereof" ${ }^{172}$ and the

163 See text and the accompanying notes 113-20 supra.

1641974 Report of the Conatisston on the Status of Women, supta note 139, at 36 .

165 Id. [Art. 8(b)].

$168 \mathrm{Id}$. at 37 [Art. 8(d)].

${ }_{167} \mathrm{Cf}$. text and the accompanying notes 121-27 supra.

1es UN HunLAN RIGrTs INSTRUMENTS, supra note 99, at 39.

${ }^{169} \mathrm{Id}$. at 56-57. See also note 167 supra.

1701974 Report of the Comamsston on the Status of Women, supra note 139, at 37.

171 Id.

17: UN Huntan Rights INSTRUMENTs, supta note 99, at 39 [Art. 6(1)(b)]. 
"same rights as men with regard to the law on the movement of persons." 173 The Draft Convention, reinforcing this provision, specifies in Article 15 that women be accorded "equal civil and legal capacity with men in all stages of procedure in courts and tribunals" ${ }^{174}$ and that "all contracts directed at restricting the legal capacity of women" be deemed "null and void." ${ }^{175}$ Article 15(4) further includes "the freedom to choose residence" in the protection regarding the "movement of persons." 176

In regard to the affection value, the Declaration, in Article 6(2)(b) and (c), stipulates that "[a]1l appropriate measures" be taken to "ensure the principle of equality of status of the husband and wife," especially that women be accorded "the same right as men to free choice of a spouse and to enter into marriage only with their free and full consent," ${ }^{177}$ and be accorded "equal rights with men during marriage and at its dissolution." 178 Emphasizing the "paramount" importance of "the interest of the children," the Declaration adds in Article 6(2)(c) that parents be accorded "equal rights and duties in matters relating to their children." ${ }^{170}$ The adoption of this provision, despite considerable opposition based on the alleged threat to "the stability of the family" as an institution," 180 was designed to "establish the principle of sharing responsibilities between father and mother." 181 In addition, the Draft Convention specifically urges in Article 16(e) "[r] ecognition of equal rights to be guardians and trustees, and also of an equal right to adopt children." 182 In a further effort to ensure equal respect for women in reference to the affection value, the Declaration in Article 6(3) prohibits "child marriage and betrothal of young girls before puberty," 183 and requires states to "specify a minimum age for marriage and to make the registration of marriages in an official registry compulsory." 184 Article 8 further stipulates that "[a]ll appropriate measures, including legislation," be taken to "combat all forms of traffic in women and exploitation of prostitution of women." ${ }^{185}$ The same provisions are embodied respectively in Article 16(2) and Article 7 of the Draft Convention. ${ }^{186}$

In concern for equal access to enlightenment and skill, the Declaration in Article 9 offers a variety of provisions:

173 Id. [Art. 6(1)(c)].

174 1974 Report of the Commission on the Status of Women, supra note 139, at 41 [Art. 15(2)].

175 Id. [Art. 15(3)]. 176 Id.

177 UN HUMAN Rugats Instrumants, supra note 99, at 39 [Art. 6(2)(a)].

178 Id. [Art. 6(2)(b)].

178 Id. at 40 .

180 EQUar RIGers For WoMEN, supra note 11, at 11.

181 Bruce, supra note 31 , at 388.

1821974 Report of the Comanssion on tae Status of Women, supra note 139, at 42.

183 UN HUMAN Rughts Instruments, supta note 99, at 40.

184 Id. 185 Id.

1861974 Report of tee Comanassion on tae Status of Women, supta note 139, at 42 , and 36. 
All appropriate measures shall be taken to ensure to girls and women, married or unmarried, equal rights with men in education at all levels, and in particular:

(a) Equal conditions of access to, and study in, educational institutions of all types, including universities and vocational, technical and professional schools;

(b) The same choice of curricula, the same examinations, teaching staff with qualifications of the same standard, and school premises and equipment of the same quality, whether the institutions are co-educational or not;

(c) Equal opportunities to benefit from scholarships and other study grants;

(d) Equal opportunities for access to programmes of continuing education, including adult literacy programmes;

(e) Access to educational information to help in ensuring the health and well-being of families. ${ }^{187}$

Paragraph e, a "very carefully drafted phrase," 188 is said to be "the first-even though very indirect-reference to certain aspects of family planning in an international instrument emanating from the Commission on the Status of Women." 189 Essentially the same provision appears in Article 10 of the Draft Convention. ${ }^{190}$

In an effort to "ensure to women, married or unmarried, equal rights with men in the field of economic and social life," Article 10(1) of the Declaration calls for "appropriate measures" to protect certain rights:

(a) The right, without discrimination on grounds of marital status or any other grounds, to receive vocational training, to work, to free choice of profession and employment, and to professional and vocational advancement;

(b) The right to equal remuneration with men and to equality of treatment in respect of work of equal value;

(c) The right to leave with pay, retirement privileges and provision for security in respect of unemployment, sickness, old age or other incapacity to work;

(d) The right to receive family allowances on equal terms with men. ${ }^{101}$

The same article prescribes, in paragraph 2, certain special protection for women's "effective right to work" in requiring that measures be taken to "prevent" women from being dismissed "in the event of marriage or maternity" and to "provide paid maternity leave, with the guarantee of returning to former employment" and also to "provide the necessary social services, including childcare facilities." ${ }^{192}$ The article further makes it clear that "measures taken to protect women in certain types of work, for reasons inherent in their physical nature," are not to be regarded as

187 UN HUMAN RIGHTS INSTRUMENTs, supra note 99, at 40.

188 Equar Rugits for Women, supra note 11, at 16.

189 Id.

1901974 Repont of the Comarssion on the Status of Women, supra note 139, at $37-38$.

191 UN HUMan Rrgers Instruments, supra note 99, at 40.

192 Id. 
discriminatory. ${ }^{203}$ A very explicit provision for protection of women in the wealth process appears elsewhere, in Article 6(I)(a), which ensures to "women, married or unmarried, equal rights with men" to "acquire, administer, enjoy, dispose of and inherit property, including property acquired during marriage." 194

The Draft Convention offers more detailed protection in terms of both wealth and well-being. Thus, for example, Article 11(a) specifies women's "right to work" to include "the right of all persons to an opportunity to earn their livelihood by work which they freely choose or to which they freely consent and the right to be employed in their field of specialization in accordance with their level of qualifications" 195 and under Article 11(b) women are to be assured the "right to take employment and to continue their activity in the labour force and in professions irrespective of marital status or of spouse's consent." ${ }^{198}$ Article 11(d) further specifies the right of women to "receive equal initial or basic vocational training for preparation for employment, and advanced training on an equal footing with men for promotion and in the event of changes in the conditions of production or technical advances and, where necessary, free retraining and restoration of levels of qualification after an enforced interruption resulting from the fulfilment by women of their maternal obligations." ${ }^{207}$ Other measures adopted "for the protection of women" because of "their physical nature and for the promotion of the welfare of mothers," which in the words of Article 4(2) are not to be "interpreted as violating the principle of equality of rights of men and women," 108 include the following:

(1) Protection of women workers from "heavy labour and under working conditions that are physically harmful to women" [Art. 12(a)]; ${ }^{100}$

(2) Provision of "appropriate working conditions for pregnant women and nursing mother" [Art. 12(b) ]; 200

(3) Grant of "adequate maternity leave with pay" and "without loss of the job held" [Art. 12(c)]; ${ }^{201}$

(4) Prohibition on dismissing women on maternity leave or on account of their being "pregnant" or "nursing a child" [Art. 12(d)]; ${ }^{202}$

(5) Adequate pay leave to accommodate childcare needs [Art. 12(e) and (f) $] ;{ }^{203}$

(6) Provision to women of "free medical care during pregnancy, confinement and the post-natal period" [Art. 12(g)]; ${ }^{204}$

(7) Provision of adequate childcare facilities and services [Art. (13)], ${ }^{206}$

The Draft Convention makes it clear, further, that the proposed measures of protection for women in the fields of wealth and well-being are intended

193 Id. [Art. 10(3)]. 194 Id. at 39.

1951974 REPORT of the COMMIssion ON THE Status of WOMEN, supra note 139, at 38 .

190 Id.

$198 \mathrm{Id}$. at 35 .

$200 \mathrm{Id}$.

$202 I d$.

$199 \mathrm{Id}$. at 39.

$201 \mathrm{Id}$. at 40.

208 Id.

203 Id.

$205 \mathrm{Id}$. at $40-41$. 
for wide application. Thus, Article 14 reads:

The provisions of articles $11,12,13$ and 14 shall apply to all women without exception, who are gainfully employed in State co-operative, public and private institutions, industrial and non-industrial enterprises and other organizations in agriculture and on plantations, and also to women who perform for any organizations or individuals remunerated work at home or who are gainfully employed in domestic work. ${ }^{205}$

Finally, to eliminate double standards in relation to responsible conduct, the Declaration stipulates in Article 7 that "[a]11 provisions of penal codes which constitute discrimination against women shall be repealed." ${ }^{20 \tau}$ This is primarily designed to protect women against prosecution for certain crimes hitherto uniquely ascribed to women or crimes in which double standards are employed in defining the crimes..$^{208}$

The profound concern for eradicating discrimination on account of sex contained in the Declaration and the Draft Convention is fortified by many parallel expressions emanating from various United Nations and related bodies. ${ }^{200}$ The Proclamation of Teheran, adopted by the International Conference on Human Rights in May 1968, appropriately summarizes:

The discrimination of which women are still victims in various regions of the world must be eliminated. An inferior status for women is contrary to the Charter of the United Nations as well as the provisions of the Universal Declaration of Human Rights. The full implementation of the Declaration of the Elimination of Discrimination against Women is a necessity for the progress of mankind. ${ }^{210}$

The call of the Conference for "measures to promote women's rights in the modern world, including a unified long-term United Nations programme for the advancement of women" ${ }^{211}$ was soon followed up by the General Assembly in adopting such a program in 1970.212 In its resolution on "International Development Strategy for the Second United Nations Development Decade," adopted in October 1970, the General Assembly included among the "goals and objectives" of the Decades the encouragement of "the full integration of women in the total development effort." ${ }^{213}$ In order to further "strengthen universal recognition of the principle of the equality

200 Id. at 41.

go7 UN HUAnAN RIGHTS INsTRUnIENTs, supra note 99, at 40.

20s Other examples include application of double standards to "such matters as adultery and even murder in certain instances, where the husband was permitted to plead reasons of personal honour to justify killing of his wife in certain circumstances." Equal Rights for WoMen, supra note 11 at 15. See also B. BABCock, A. Freedacan, E. Norton, \& S. Ross, supra note 6, at 819-914; Bruce, supra note 31, at 389.

"20y Cf. Untred Nattons, The United Nations and the Status of Women (1964); Bruce, supra note 31.

:10 UN HUMan Rughts Instronfents, supra note 99, at 19; UNITEd Nations, FinaL Act of the International Conference on Hundan Rights, Teheran, 22 Apru to 13 MAY 1968, at 4, UN Doc. A/CONF.32/41 (1968) [hereinafter cited as FINAI ACT of twe Human Rughts Conference].

:11 Finat Act of the Human Rughts Conference, supra note 210, at 10-11.

212 GA Res. 2716, GAOR, 25th Sess., Supp. 28, at 81-83, UN Doc. A/8028 (1970).

$213 \mathrm{GA}$ Res. 2626, id., at 39, 41 . 
of men and women, de jure and de facto," ${ }^{214}$ the General Assembly, in its resolution 3010 of December 18, 1972, proclaimed "the year 1975 International Women's Year." 215 It urges "intensified action" to "promote equality between men and women" and to "ensure the full integration of women in the total development effort." 216

On the regional level, sex is included among the impermissible grounds of differentiation in both the European Convention on Human Rights and the American Convention on Human Rights. The European Convention states in Article 14 that "the enjoyment of the rights and freedoms" provided in the Convention are to be "secured without discrimination" because of sex or other grounds. ${ }^{217}$ The American Convention, in Article $1(1)$, obliges the contracting states to "undertake to respect the rights and freedoms" provided in the Convention and to "ensure to all persons subject to their jurisdiction the free and full exercise of those rights and freedoms, without any discrimination" on account of "sex" or other factors. ${ }^{218}$ It may be noted that even before the adoption of the American Convention of Human Rights in November, 1969, significant achievements for the protection of women had been made under the Inter-American System, which considerably inspired the work of the UN bodies in the protection of women's rights. ${ }^{219}$ Beginning with the concern for protecting women's rights, as expressed in the Fifth International Conference of American States in $1923,{ }^{220}$ through the establishment and functioning of the InterAmerican Commission of Women, ${ }^{221}$ a number of regional prescriptions for the protection of women had come into being. Notably, the Montevideo Convention on the Nationality of Women of 1933 pioneered the principle of equality of sexes regarding nationality: "There shall be no distinction based on sex as regards nationality in their legislation or in their practice" (Art. 1). ${ }^{222}$ The Lima Declaration in Favor of Women's Rights, adopted

214 GA Res. 3010, GAOR, 27th Sess., Supp. 30, at 66, UN Doc. A/8730 (1972).

215 Id. at 67.

216 Id. See also notes 2 and 3 stupra.

217 Bastc Documents on Internationar Protection of Human Rughts 125, 130 (L. Sohn \& T. Buergenthal eds. 1973) [hereinafter cited as Basic Documants]. The Rome Treaty of 1958, etablishing the European Economic Community, states, in Article 119, that "each member State shall apply the principle of equal pay for men and women in the case of the same work."

218 Basic Documents, supra note 217, at 210.

2i9 See Organtzation of amerucan States, Generar Secruetaruat, The Onganization of AMERICAN States ANd Human Rugets, 1960-1967, at 69-79 (1972) [hereinafter cited as OAS AND HUMAN Rugars]. Report Submitted by the Organization of American States 68-80, UN Doc. A/CONF.32/L.10 (1968) [hereinafter cited as OAS Report].

220 See OAS AND Human Rughts, supra note 219, at 69; OAS Report, supra note 219 , at 68-69.

221 OAS AND HUMAN Rugrrs, supra note 219, at 69-70; OAS Report, supra note 210, at 69-70. For accounts of the recent activities of the Inter-American Commission of Women, see Report of the Inter-American Commission of Women, UN Doc. E/CN.6/ 558 (1972); Programme of Concerted International Action to Promote the Advancement of Women and Their Integration in Development (Report of the Inter-American Commission of Women), UN Doc. E/CN.6/572 (1973).

222 Nationality OF Marrued Women, supta note 123, at 23-24. 
at the Eighth International Conference of American States in $1938,{ }^{223}$ emphatically pronounced that "women have the right" to "political treatment on the basis of equality with men," to "the enjoyment of equality as to civil status," to "full protection in and opportunity for work," and to "the most ample protection as mothers." ${ }^{224}$ In 1948, at the Ninth Conference of the Organization of American States held in Bogota, Colombia, the long years of efforts on the part of the Inter-American Commission of Women culminated in the adoption of two separate conventions: the Inter-American Convention on the Granting of Political Rights to Women, stipulating that "the right to vote and to be elected to national office shall not be denied or abridged by reason of sex"; ${ }^{225}$ and the Inter-American Convention on the Granting of Civil Rights to Women, pursuant to which the contracting states pledge to "grant to women the same civil rights that men enjoy." ${ }^{226}$ Meanwhile, the American Declaration of the Rights and Duties of Man, adopted at the same Conference and antedating the Universal Declaration of Human Rights, also pronounced in Article 2 that

All persons are equal before the law and have the rights and duties established in this Declaration, without distinction as to race, sex, language, creed or any other factor. ${ }^{227}$

The accelerating movement toward the reform of national constitutions to secure equal rights for women adds substance to transnational expectations in behalf of nondiscrimination. The United States offers an excellent example. A long line of judicial decisions, slowly enlarging the rights of women, ${ }^{228}$ and changing community expectations have culminated in a proposed Equal Rights Amendment to the Constitution which is in the process of being ratified. The substantive sections of the proposed Equal Rights Amendment, as passed by the U.S. Congress on March 22, 1972, read as follows:

Section 1. Equality of rights under the law shall not be denied or abridged by the United States or by any State on account of sex.

Section 2. The Congress shall have the power to enforce, by appropriate legislation, the provisions of this article. ${ }^{229}$

223 Carnegie Endowarent for International Peace, The International Conferences of Aderican States, Fmst Suppleatent, 1933-1940, at 250 (1940).

224 Id.

225 Convention on the Political Rights of Wonien, supta note 114, at 4.

226 Id. (n. 6).

2L7 BAsic Documents, supta note 217, at 187, 188.

228 See N. Donsen, N. Chachows, \& S. LAw, supra note 44, at 347-90. Cf. also B. Babcock, A. Freedican, E. Norton, \& S. Ross, supta note 6; K. Davioson, R. GinsBuRG, \& H. KAY, supra note 6; L. KANOwITZ, supra note 15.

220 As of August 24, 1974, 33 states out of the required 38 had ratified the Amendment. N.Y. Time, Aug. 24,1974 , at 12, col. 1 (city ed.). The tortuous legislative history of this amendment is indicated in Brown, Emerson, Falk, \& Freedman, supra note 6, at 981-85. See also Hearings on S.J. Res. 61 Before the Subcomm. on Constitutional Amendments of the Senate Comm. on the Judiciary, 91st Cong., $2 \mathrm{~d}$ Sess. (1970); Hearings on S.J. Res. 61 and S.J. Res. 231 Before the Senate Comm. on the Judiciary, 91st Cong., 2d Sess. (1970); House Hearings on Equal Rights, supra note 
From the decision in Bradwell v. Illinois (1873), ${ }^{230}$ sanctioning the exclusion of women from the legal profession, as grounded in the anachronistic doctrine of "women's separate place" in society, the United States Supreme Court had moved a long way when, in 1971, it held unconstitutional, in Reed $v$. Reed, ${ }^{231}$ an Idaho statute purporting to favor males over females in the matter of administering estates. In the words of the Court:

To give a mandatory preference to members of either sex over members of the other, merely to accomplish the elimination of hearings on the merits, is to make the very kind of arbitrary legislative choice forbidden by the Equal Protection Clause of the Fourteenth Amendment; and whatever may be said as to the positive values of avoiding intrafamily controversy, the choice in this context may not lawfully be mandated solely on the basis of sex..$^{232}$

The emerging prescription is further fortified by Frontiero v. Richardson (1973), ${ }^{233}$ in which the Supreme Court declared unconstitutional statutes which allow a serviceman to claim his wife, "for the purposes of obtaining increased quarters allowances and medical and dental benefits," "as a 'dependent' without regard to whether she is in fact dependent upon him for any part of her support" " 234 but disallows a servicewoman to "claim her husband as a 'dependent" "unless he is in fact dependent upon her for over one-half of his support." ${ }^{235} \mathrm{Mr}$. Justice Brennan, announcing the judgment of the Court and speaking for himself and three other Justices, observed that

since sex, like race and national origin, is an immutable characteristic determined solely by the accident of birth, the imposition of special disabilities upon the members of a particular sex because of their sex would seem to violate "the basic concept of our system that legal burdens should bear some relationship to individual responsibility." 230

"And what differentiates sex," Justice Brennan elaborates, "from such nonsuspect statuses as intelligence or physical disability, and aligns it with the recognized suspect criteria, is that the sex characteristic frequently bears no relation to ability to perform or contribute to society. As a result, statutory distinctions between the sexes often have the effect of invidiously relegating the entire class of females to inferior legal status without regard to the actual capabilities of its individual members." ${ }^{237}$ "[C]lassifications based upon sex," he adds, "like classifications based upon race, alienage, or national origin, are inherently suspect, and must therefore be subjected to strict judicial scrutiny." 238 "Applying the analysis mandated by that

349; Women and the "Equal Rights" Amendient: Senate Subcommtttee Hearungs on the Constitutional Amendment, 91st Congress (C. Stimpson ed. 1972); B. Batcock, A. Freedman, E. Norton, \& S. Ross, supra note 6, at 129-89.

230 Bradwell v. Mllinois, 83 U.S. (16 Wall.) 130 (1873).

${ }^{231}$ Reed v. Reed, 404 U.S. 71 (1971).

232 Id. at 76-77.

233 Frontiero v. Richardson, 411 U.S. 677 (1973).

$234 \mathrm{Id}$. at 678.

$230 I d$. at 686 .

235 Id. at $678-79$.

237 Id. at $686-87$.

$238 \mathrm{Id}$. at 688 . 
stricter standard of review," 239 Justice Brennan concluded that,

by according differential treatment to male and female members of the uniformed services for the sole purpose of achieving administrative convenience, the challenged statutes violate the Due Process Clause of the Fifth Amendment insofar as they require a female member to prove the dependency of her husband.240

The Reed and Frontiero decisions undoubtedly harbinger a great potential for both the Fifth and the Fourteenth Amendments in coping with sexbased discriminations. Nevertheless, insistent demands continue that the Equal Rights Amendment be ratified without delay. As Emerson and his co-authors eloquently put it,

We believe that the necessary changes in our legal structure can be accomplished effectively only by a constitutional amendment. The process of piecemeal change is long and uncertain; the prospect of judicial change through interpretation of the Fourteenth Amendment is remote and the results are likely to be inadequate. The Equal Rights Amendment provides a sound constitutional basis for carrying out the alterations which must be put into effect. It embodies a consistent theory that guarantees equal legal rights for both sexes while taking into account unique physical differences between the sexes. In the tradition of other great constitutional mandates, such as equal protection for all races, the right to freedom of expression, and the guarantee of due process, it supplies the fundamental legal framework upon which to build a coherent body of law and practice designed to achieve the specific goal of equal rights. ${ }^{241}$

A comprehensive comparative study, while it presumably would reveal considerable diversity in the detailed practice of different communities, would certainly confirm a trend toward prescription of equality between the sexes. ${ }^{242}$ As noted elsewhere, it is practically a universal pattern in national constitutions to prescribe a general form of equality, which typically condemns sex, along with race and other factors, as a basis of differential treatment. ${ }^{243}$ Many constitutions have gone further by enunciating separate provisions for equality of the sexes, explicitly highlighting equal rights for women as well as men. Thus, the 1949 Constitution of the German Federal Republic declares, in Article 3(2), that "[m]en and women shall have equal rights." 244 The 1936 Constitution of the USSR

239 Id.

$240 I d$. at $690-91$.

241 Brown, Emerson, Falk, \& Freedman, supra note 6, at 979. With or without appropriate constitutional amendment, lawyers engaged in litigation for the protection of human rights might make much more effective use of the transnational prescriptions outlined above. Irrespective of whether particular conventions have been ratified by the United States, the general norm of nondiscrimination could be found to be a part of the customary international law which is the law of the land of the United States.

2:2 See e.g., Untted Nations, Constirutions, Electoral Laws aNd Other Legat Instruments Relating to the Polrtical Rights of Women, UN Doc. A/6447/Rev.1 (1968); Symposium-The Status of Women, 20 Axr. J. Coxip. L. 585 (1972).

243 See McDougal, Lasswell, \& Chen, supra note 4.

244 Basic Documents on Human Rights 19 (I. Brownlie ed. 1971). 
states in Article 122:

Women in the U.S.S.R. are accorded equal rights with men in all spheres of economic, government, cultural, political and other public activity.

The possibility of exercising these rights is ensured by women being accorded an equal right with men to work, payment for work, rest and leisure, social insurance and education, and by state protection of the interests of mother and child, state aid to mothers of large families and unmarried mothers, maternity leave with full pay, and the provision of a wide network of maternity homes, nurseries and kindergartens. ${ }^{245}$

Similarly; Article 96 of the Constitution of the People's Republic of China, 1954, reads:

In the People's Republic of China women enjoy equal rights with men in all spheres-political, economic, cultural, social and domestic.

The state protects marriage, the family, and the mother and child. ${ }^{240}$

Article 51 of the Constitution of Paraguay, 1967, provides:

This Constitution upholds the equality of the civil and political rights of men and women, whose correlative duties shall be established in the law, attending the purposes of matrimony and to the unity of the family. ${ }^{247}$

Quite recently, the new Constitution of Egypt, adopted in 1972, stipulates in Article 11 that "[ $t]$ he State shall reconcile women's duties to their families and women's work in society and shall ensure the equality of women with men in the political, social, cultural and economic fields, without violating the law of the Islamic Sharia." 248

Oftentimes protection of equal rights for women is sought through statutes. For instance, Israel's Woman's Equal Rights Law, 5711-1951, stipulates that "[w]ith regard to any legal act, the same law shall apply to a woman and a man, and any provision of law that discriminates against

${ }^{245}$ Id. at 26. See Tay, The Status of Women in the Soviet Union, 20 AM. J. Comp. L. 662 (1972).

246 Baste Docoments on Human Rughts, supta note 244, at 48.

2474 Constitutions of Nations 1067, 1074 (A. Peaslee ed. rev. 3d ed. 1970).

248 Implementation of the Declaration on the Elimination of Discrimination Against Women and Related Instruments (Report of the Secretary-General) 11, UN Doc. E/CN.6/571 (1973).

Of course what is meant by "the law of the Islamic Sharia" is critical here. In aid of interpretation, consult generally 1 A. Art, MABOMMEDAN LAw (4th ed. 1912); 2 A. Ali, Mahommedan Law (5th ed. 1929); A. Ali, The Spintr of Isladi (1022), especially at 222-57; J. ANDERson, Istando LAW IN Afruca (1954); J. ANDEnson, Istanma LaW IN the Modern Wortd (1959); A. MeEr, The Legal PostTion of WOMEN IN IstaM (1912); R. Roberts, THe Soctat Laws OF THE QuORAN (1925); J. Schacht, Introduction to Istamac Law (1964). Cf. also H. Gibd, Modern Trends IN ISLAM (1947; 1972); H. GBB, MOHAMMmEdNISM: AN Historucal Sunvey (2d ed. Galaxy Book ed. 1962); H. GrBb, Studies on the Crvarzation of IsLaM (1962; 1968); M. Qutb, IstaM, The Musunderstood Retigion (1969); W. SMITH, IsLaMs in Modern History (1957); Themes of Istamic Civinzzation (J. Williams ed. 1971). 
women as women shall be of no effect." ${ }^{249}$ The General Federation of Iraqi Women Act (No. 13 of 1972) spotlighted "the need to raise the level of women by all possible means and to ensure their enjoyment of equal rights with men in all political, social, civic, economic and cultural fields, to provide them with employment opportunities, to defend their rights and interests and to abolish existing laws, customs, regulations and practices which are discriminatory against women." 250 Other examples are documented in the Reports of the UN Secretary-General on "Implementation of the Declaration on the Elimination of Discrimination against Women and Related Instruments." ${ }^{251}$ A report of the Secretary-General points out, in sum, that "on the whole, a trend exists in those countries where full compliance in law with the provisions of the Declaration has not yet been achieved, towards the realization of a greater measure of compliance, if not total compliance in law, with the rights set forth in this international instrument." 252

IV.

\section{Proposals for Application}

The contemporary provision for implementation and application of the vast body of transnational prescriptions designed to secure equality of women with men is even more primitive than that designed to minimize racial discrimination. ${ }^{263}$ In 1968, one year after the adoption of the Declaration on the Elimination of Discrimination against Women, the Economic and Social Council, acting on the recommendation of the Commission on the Status of Women, adopted a resolution, urging such "measures of implementation" as "publicity," "studies," revision of "national legislation," and, more importantly, a reporting system. ${ }^{254}$ Needless to say, measures wholly dependent upon state cooperation, such as these, are scarcely adequate to the critical tasks of "implementation." It has increasingly been stressed that-given the decentralized character of the world arena and the complex root causes of sex-based discriminations-more comprehensive, more concerted, and more centrally directed measures are required.

The United Nations has, consequently, launched a unified long-term program for the advancement of women. ${ }^{265}$ This comprehensive program is designed, by promoting peoples' understanding, to generate changes in effective power which will make official application, national and trans-

${ }^{249}$ Quoted in Albeck, The Status of Women in Israel, 20 AM. J. Comp. L. 693 (1972).

250 Implementation of the Declaration, supra note 248 , at 12.

251 See e.g., UN Doc. E/CN.6/548 (1971); UN Doc. E/CN.6/571, supra note 248.

262 UN Doc. E/CN.6/548, supra note 251, at 15.

${ }^{253} \mathrm{Cf}$. McDougal, Lasswell, \& Chen, supra note 4.

254 ECOSOC Res. 1325, ECOSOC, 44th Sess., Supp. 1, at 13, UN Doc. E/4548 (1968).

${ }^{285}$ GA Res. 2716, GAOR, 25th Sess., Supp. 28, at 81-83, UN Doc. A/8028 (1970). 
national, easier. ${ }^{256}$ The program is arranged to celebrate International Women's Year. Following the General Assembly proclamation of the year 1975 as International Women's Year, ${ }^{207}$ the Commission on the Status of Women devoted itself to working out a comprehensive program of activities, ${ }^{258}$ which was approved by the Economic and Social Council in May 1974. ${ }^{259}$ Seeking to "promote equality between men and women," "ensure the full integration of women in the total development effort," and "increase the contribution of women to the development of friendly relations and co-operation among States and to the strengthening of world peace." 260 the International Women's Year projects this central theme"Equaltty, Developarent and Peace." 261 This program, comprehensive and detailed, is addressed, in the hope of active participation, to "Member States, the United Nations, the specialized agencies, regional intergovernmental organizations, the national and international organizations and non-governmental organizations in consultative status concerned." 202 In addition to the projected "activities at the regional and international levels," ${ }^{263}$ the program urges states to undertake a variety of measures, including "special acts of commemoration," 284 mapping out national priorities and programs, ${ }^{265}$ creation of special bodies, ${ }^{200}$ "publicity and educational measures," 287 "studies and surveys," ${ }^{288}$ holding conferences, 200 "exchange programs," 270 and "ratification and implementation of international instruments." ${ }^{271}$ With all these changes in perspectives and new activities, the prospects for a more effective application of the now widely accepted norm of nondiscrimination would appear to be substantially enhanced.

It is highly probable that in future years these recent initiatives will be sustained and extended by currents that pervade the global community.

${ }^{256}$ See Untred Nations, Untted Nations Assistance for the Advancement of WoMEN, UN Doc. E/CN.6/467 (1967); UNItEd Nations, The UNITEd NATtons aNd Human Rugets 66-72 (1973); Bruce, supra note 31, at 391-412; Implementation of a Programme of Concerted International Action (Report of the Secretary-General), UN Doc. E/CN.6/577 (1973); Further Elaboration of a Programme of Concerted Action (Report of the Secretary-General), UN Doc. E/CN.6/553 (1972). Cf. also UNITED Nations, Participation of Women in Communtty Development, UN Doc. E/CN.6/ 514/Rev. 1 (1972); UNITEd NATTONS, REPORT OF the INTERREgronal MEeting OF Experts on the INTEgration of Women IN Development, UN Doc. ST/SOA/120 (1972).

257 GA Res. 3010, supra note 214.

2581974 REPORT of tHE CommIssion on THE Status of Women, supra noto 139, at $1-3,20-27,103-13$. Regarding the Commission's deliberations at its twenty-fifth session, see UN Docs. E/CN.6/SR.599-612 (1974).

259 ECOSOC Res. 1849 (LVI), May 16, 1974, UN Doc. E/RES/1849 (1974). See also International Women's Year: Report of the Secretary-General, UN Doc. E/CN.6/ 576 (1973); International Women's Year: Report of the Working Group to the Commission on the Status of Women, UN Doc. E/CN.6/588 (1974); note 1 supra.

280 ECOSOC Res. 1849 (LVI), supra note 259 , at 3.

$201 \mathrm{Id}$.

203 Id. at 11-13.

205 Id. at $7-8$.

267 Id. at 8-10.

269 Id. at 11 . 262 Id. at 1.

264 Id. at 7 .

${ }^{268} I d$. at 8.

$268 \mathrm{Id}$. at 10.

271 Id.

270 Id. 
The degree to which effective application of the new prescriptions forbidding sex-based discrimination can be secured will of course depend in measure upon how human rights in general, and especially all the other rights to equality projected in the more general norm of nondiscrimination, are protected and fulfilled. Since many of the deprivations imposed upon women are attributable to long-held traditions about the unique role ascribed to them in childbearing and child rearing, it is possible that the explosive growth of the biological sciences will exert a profound influence on the role-separation of the sexes. It may, for example, no longer be necessary for the embryo to spend its formative months enclosed in the female body. As the biological constraints of an earlier day are transmuted into biological and cultural choices and the function of the family in social process changes, the alternatives open to world public order will be less and less constrained by yesterday's rationalizations of sexual difference as a means of justifying the subordination of women. Similarly, even some of the least welcome tendencies in the world arena, such as the persisting expectations of violence, may contribute to the elimination of discriminations that have been traditionally justified in terms of sex. In a world of universalizing science-based technology, an outstanding consequence of war and preparation for war must be the socialization of risk. No massive barrier can be made to separate danger "at the front" from the threats to which the civilian population is exposed. It may, thus, be increasingly recognized as foolhardy for a public order to maintain discriminations directed against half its population, compromising the security of the whole by failing to enlist and employ the latent capabilities of the deprived half. It is, finally, most unlikely that the insistent demands of the hitherto deprived half for equality in every nook and cranny of life will lessen in intensity. 